\title{
La cerámica Celtibérica gris de imitación de vasos metálicos en el Valle del Duero: propuesta de sistematización y problemática en torno a su origen
}

\author{
J. F. Blanco García \\ Universidad Autónoma de Madrid
}

\section{Resumen}

Entre los años 130/125 y 75/70 antes de Cristo se estuvo fabricando en el centro de la Cuenca del Duero un tipo de cerámica celtibérica en pastas grises, de superficies lustrosas y tacto céreo que imitan prototipos metálicos pero en la que convergen influencias de familias y grupos cerámicos diversos. En este trabajo hemos querido centrarnos en dos aspectos básicos de estas producciones: su ordenación tipológica y la compleja problemática existente en torno a su origen.

Palabras clave: Cerámica gris. Celtibérico. Valle del Duero.

\begin{abstract}
Among the years $130 / 125$ and $75 / 70$ B.C. it was fabricated on central territories of the Duero Valley, in Spain, a type of celtiberian wheel-turned pottery characterized by the grey coloration of the clay, the polish surfaces and the smooth touch. This speciality constituted an imitation of metallic vessels, but we can to observe that another ceramic groups and families prevailed on it. In this paper we are going to analysed two basic aspects: the seriation and the problems about the origins.

Key words: Grey pottery. Celtiberian culture. Duero Valley.
\end{abstract}

\section{Cuestiones previas e historia de la INVESTIGACIÓN.}

Dentro de las diversas especialidades alfareras que conforman esa realidad arqueológica que conocemos como cerámica celtibérica, el grupo constituido por las grises y negras fabricadas en pastas muy depuradas y duras, de superficies bruñidas o pulidas que les dan un característico brillo metálico, tacto céreo, decoración incisa o impresa -cuando la llevan-, y cronología tardía que de nuevo son objeto de nuestra atención en estas páginas, es uno de los últimos que ha podido ser aislado y definido, al menos en sus parámetros básicos. No obstante, aún existen aspectos importantes y cuestiones de detalle que exigen ser resueltos para con ello alcanzar una comprensión si no total al menos lo más completa posible de todo cuanto rodea a esta parcela de la investigación del mundo material prerromano meseteño. Quizá el de menor importancia sea encontrar un nombre adecuado con el que identificar lo más ajustada y rigurosamente posible a este grupo cerámico, pues aunque todos sabemos a qué productos nos estamos refiriendo cuando hablamos de "cerámica celtibérica gris estampillada", "cerámica gris estampada cérea" o "cerámica gris de imitación de vasos argénteos", lo cierto es que como términos plenamente válidos de esas expresiones hemos de aceptar sólo su coloración gris, la textura cérea de las superficies expuestas al tacto y a la vista, y la intencionalidad de imitar recipientes argénteos o metálicos en general, notas identificativas no exentas de excepciones, como son que también los hay negros y, más excepcionalmente, anaranjados, con las superficies simplemente alisadas y ásperas al tacto en algunos casos. La referencia al carácter de producción decorada por medio de estampillas es sólo una verdad a medias sustentada en la circunstancia de que del repertorio formal del grupo los tipos de vasos más abundantes son los caliciformes (Fig. 6) y como en la mayor parte de ellos comparecen tales impresiones el rasgo lo hicimos nosotros mismos injustificadamente extensivo al grupo entero, cuando en realidad de los treinta y cuatro perfiles que se han discernido en la presente sistematización sólo ocho cuentan con decoración estampada, pertenecientes a cuatro de las doce formas generales en las que se han agrupado aquéllos. Es decir, esta es una especialidad cerámica que si la consideramos por el volumen de materiales conocidos, cuantitativamente, da la imagen de ser eminentemente decorada, pero analizada desde el punto de vista de la variabilidad morfológica nos encontramos con que son las formas lisas las que verdaderamente predominan. 
1
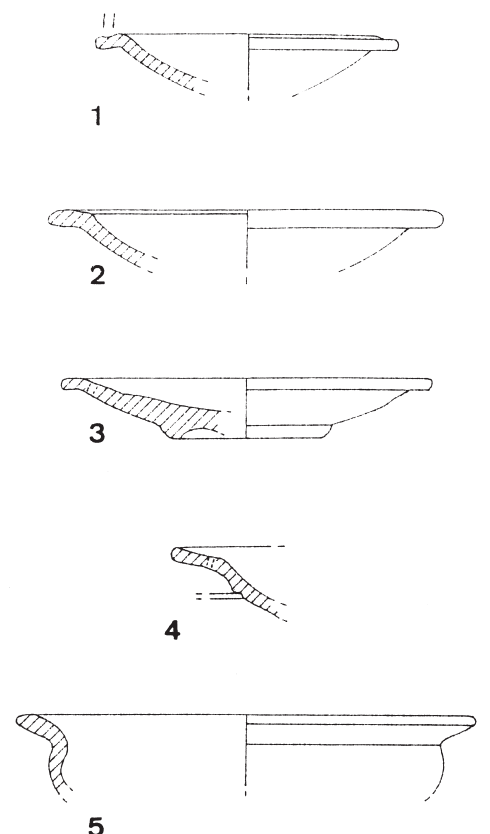

V

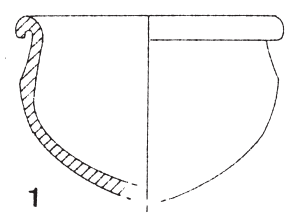

VI
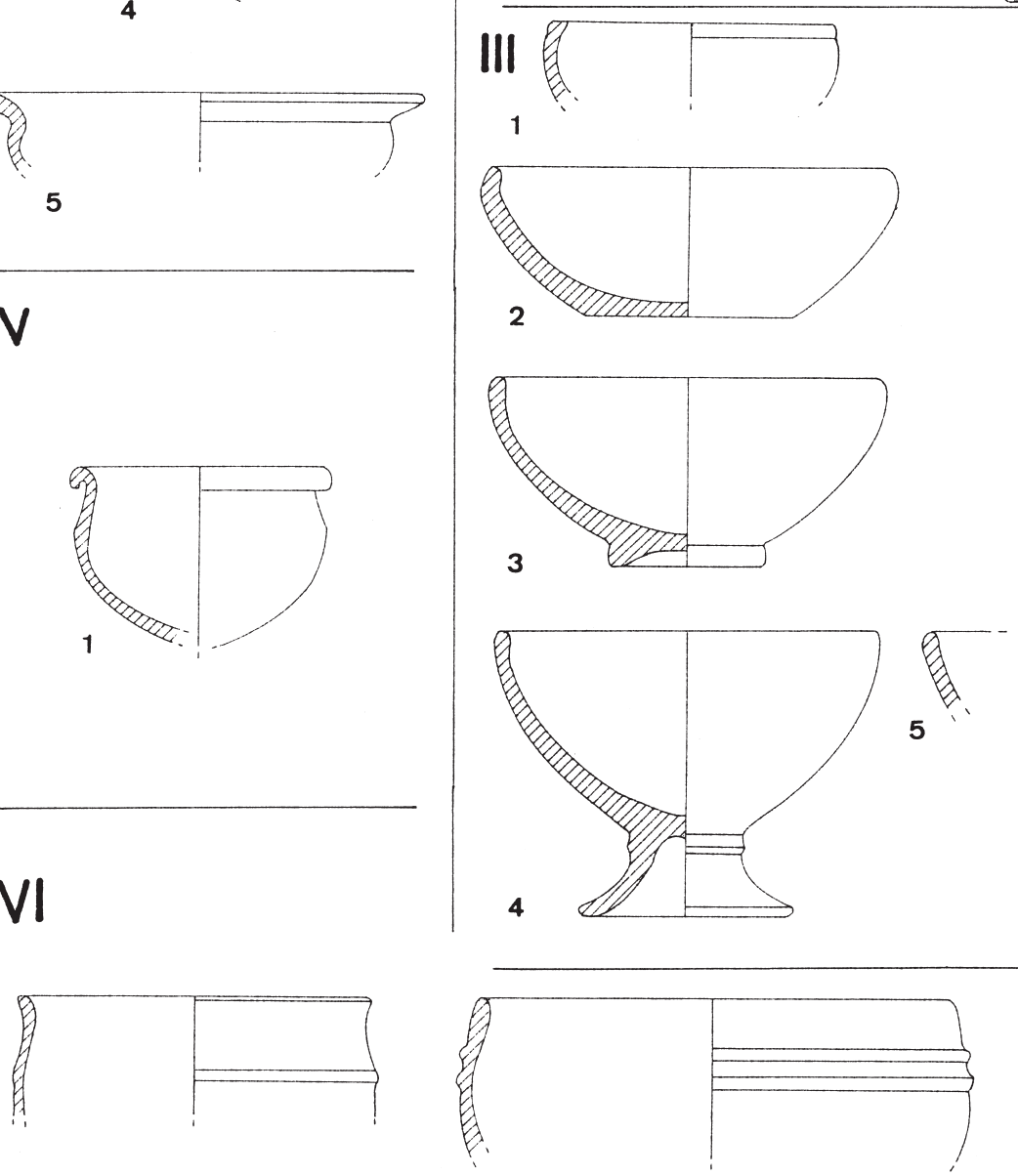

IV

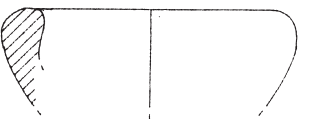

1
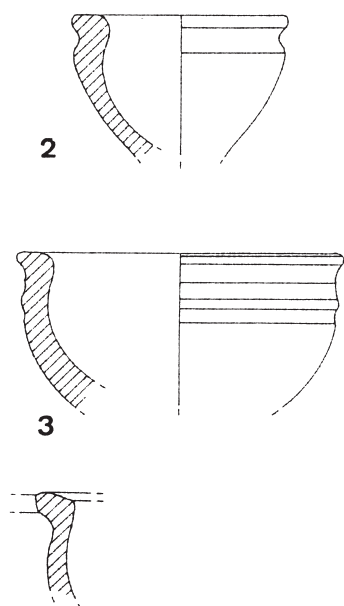

4
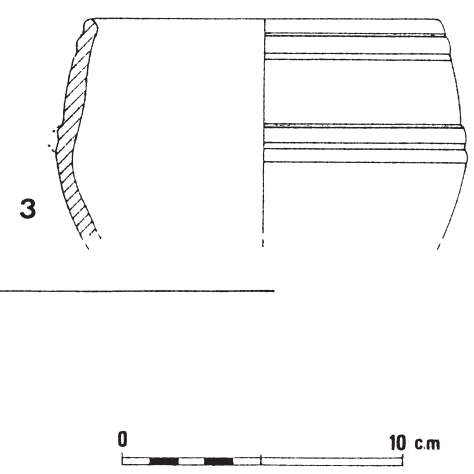

Figura 1.- Tabla de formas. 
Pero todo esto tiene una importancia secundaria con relación a otros problemas cuyas soluciones nos acercarían a una mejor comprensión de las poblaciones que usaron estos recipientes. Más trascendencia tiene, por ejemplo, averiguar las posibles causas que llevaron a la creación de esta especialidad cerámica cuando las necesidades prácticas estaban aparentemente más que cubiertas con las producciones finas oxidantes. Se podría pensar que tras estas producciones se encuentran posiciones mentales y actitudes relacionadas con el concepto de prestigio social o en la posibilidad de que determinadas formas como las de cáliz hubieran surgido bien para cubrir nuevas funciones de las que por ahora poco sabemos, bien para atender otras que tradicionalmente venían realizándose en vasos metálicos y de las que tampoco sabemos mucho, pero aclarar esta problemática con los escasos datos disponibles resulta por ahora inabordable. A lo más que podemos llegar es a plantear meras hipótesis.

Problema estrechamente ligado a esta cuestión es el de las razones por las que, al parecer, en un corto periodo de tiempo la 'moda' o la necesidad para la que fue creada esta especialidad vascular se extendió por todo el centro y occidente de la Cuenca del Duero, pues no sólo se documenta entre los vacceos sino también en poblaciones vettonas y arévacas (fig. 8). Resulta muy sugerente pensar que fue precisamente el enorme atractivo estético que, sin duda, debieron de tener estos vasos para quienes los usaron el causante de tan rápida difusión y que el fenómeno bien pudiera haber surgido en una zona, poblado o incluso alfar concreto y en poco tiempo se hubiera extendido por la mayor parte de la Submeseta Norte tanto su producción como su uso, pero de haber sido así lo cierto es que nada hay por ahora que nos lo indique. Ni siquiera sería fiable intentar resolver este problema aplicando los habituales métodos estadísticos a la dispersión de materiales tal como se ha hecho con otros elementos arqueológicos como la moneda, p. ej., para intentar localizar cecas, o como las marcas de algunos fabricantes de sigillata para asociarlos a los centros de producción conocidos o deducir la existencia de otros nuevos. Conectados con esta problemática, no dejan de ser un poco chocantes dos realidades que quizá no sean más que fruto del estado en el que se encuentra la investigación pero que a estas alturas podrían estar ya indicando algo: la ausencia de cerámicas de este tipo en algunos grandes yacimientos del Duero Medio que estuvieron habitados en la época en la que se estaban produciendo y, en segundo lugar, el hecho de que aunque los vasos y fragmentos cerámicos de este grupo los encontramos muy repartidos geográficamente, salvo en Coca (Cauca) y Padilla/Pesquera de Duero (Pintia) siempre se encuentran en el resto de yacimientos en tan escaso número que nos obliga a pensar en una 'moda' que debió de calar muy poco.

Otro grupo de aspectos a dilucidar tiene que ver con el grado de "responsabilidad" que en el surgimiento de esta personalísima especialidad cerámica tuvieron todas cuantas estaban en uso, tanto locales como importadas, durante el siglo II a. C. (peinadas de Cogotas II, estampadas y grises antiguas, celtibéricas oxidantes, campanienses, etc.), así como la vajilla metálica, y más concretamente la de plata, indiscutible inspiradora de algunas formas y decoraciones concretas. En este contexto, y puesto que cada vez se conocen más ejemplos, también va siendo necesario explicar lo mejor posible cómo encajan en la formación y evolución de los caliciformes hechos a torno aquellos otros elaborados a mano que tan cercanos tipológica y decorativamente se encuentran de ellos y que por ahora sólo están presentes en Las Quintanas y el madrileño Cerro de la Gavia: ¿fueron realmente, como los vasos de plata, también prototipos? y si es así ¿por qué en Coca aún no han aparecido, cuando es el yacimiento del Valle del Duero en el que las grises torneadas son más numerosas y variadas tanto desde el punto de vista formal como ornamental?, ¿son exclusivamente anteriores a los torneados, como parece deducirse de la posición estratigráfica que ocupa la pieza padillense, o también se estuvieron fabricando simultáneamente a éstas?

No menos importante que las ya referidas es la cuestión de la evolución interna que experimenta el grupo como totalidad y cada una de las formas en particular, pues seguramente esta especialidad alfarera no surgió con la diversidad formal y decorativa con la que se nos manifiesta ante nosotros al observarla y analizarla como un conjunto homogéneo y monolítico. Dado que por el momento no se conocen los alfares de los que salieron, sino únicamente los lugares en los que estuvieron en uso y se amortizaron, y que tampoco disponemos de secuencias estratigráficas detalladas de estaciones varias que abarquen el corto periodo en el que estuvieron en uso estas cerámicas y con las que contrastar las registradas en Coca, por ahora no es posible saber con total seguridad cuáles fueron las formas que primero se fabricaron y cuáles las últimas; qué variantes, dentro de cada una de ellas, son las más antiguas, cuáles las evolucionadas y qué otras las terminales; si en las formas decoradas esa decoración nace con el tipo, se incorpora más tarde o si, por 


\section{VIII}
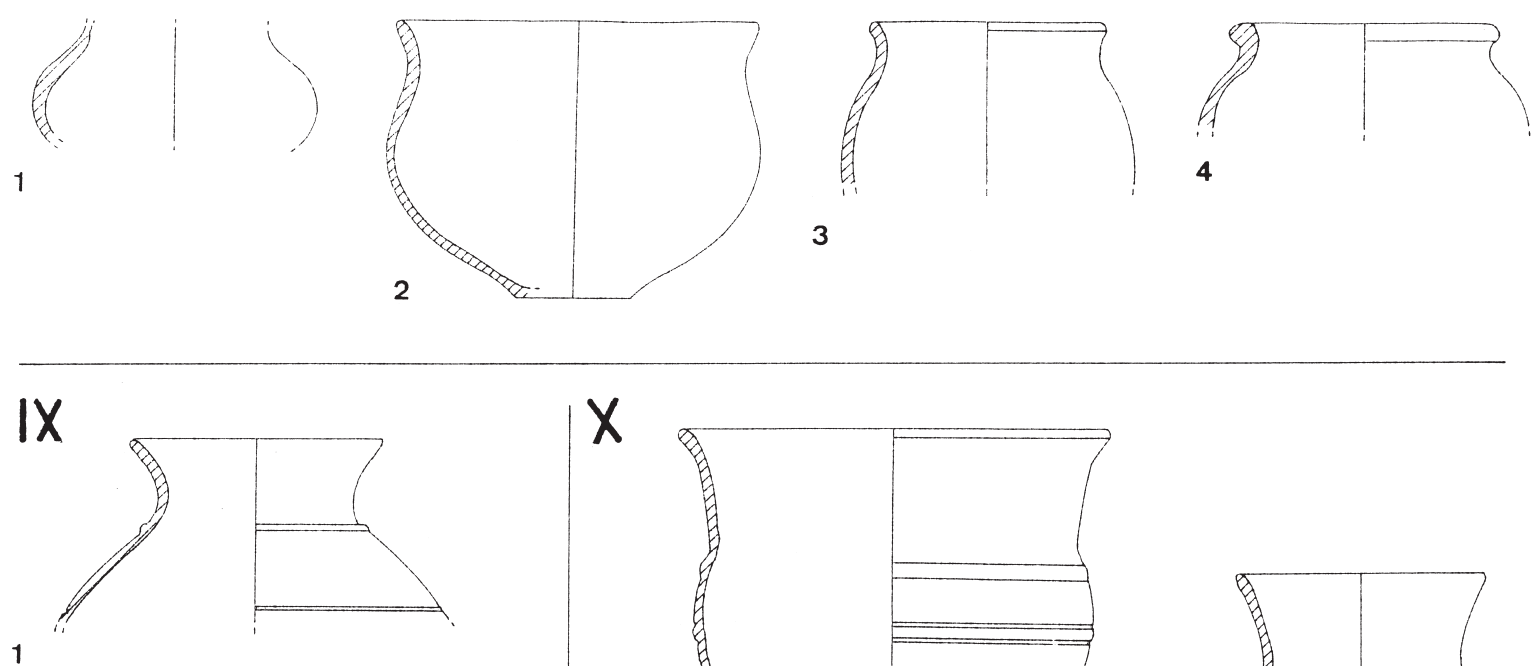

\section{X}
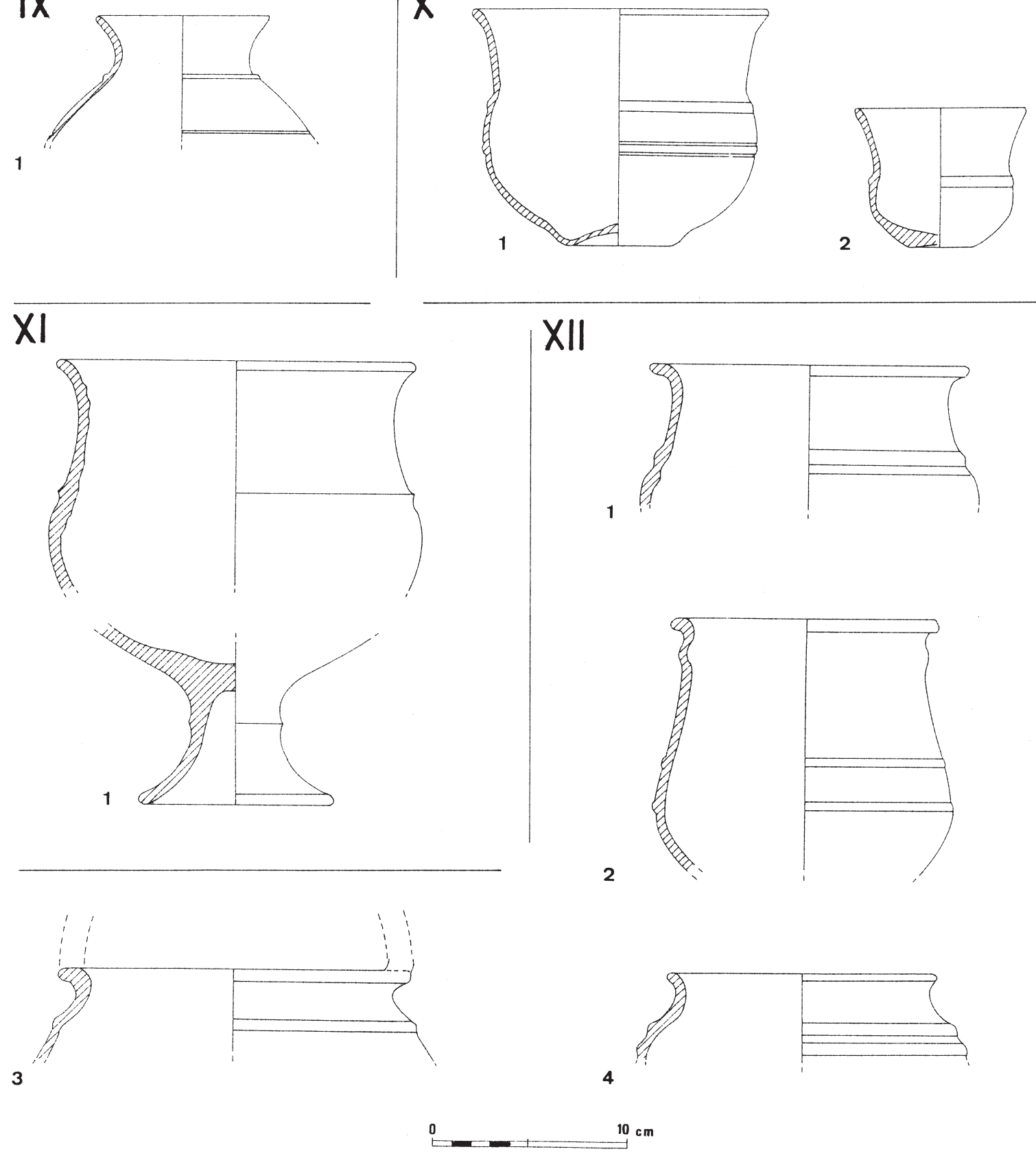

Figura 2.- Tabla de formas (Cont.). 
1.- LINEAS BRUÑIDAS A ESPÁTULA

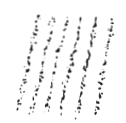

1

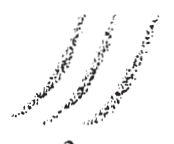

2

2.- INCISIONES

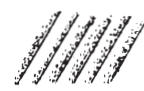

3. - REH
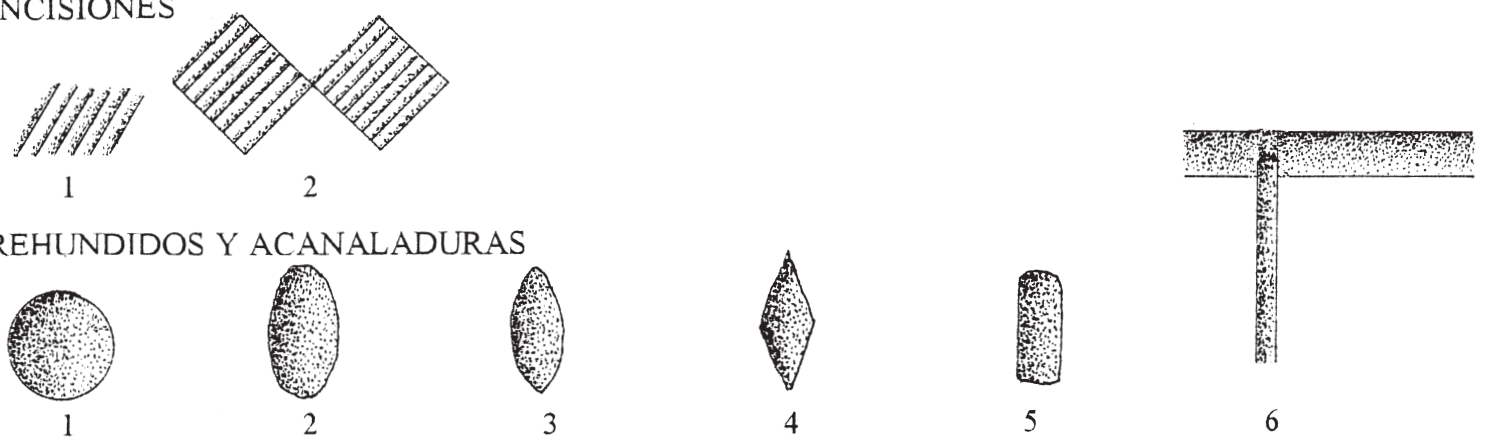

4.- IMPRESIONES SENCILLAS<smiles>C[12IH]I</smiles>

군 구운 2

5.- ESTAMPILLAS

A. Aspas

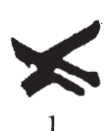

B. Cuadrangulares

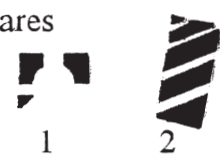

C. Circulares

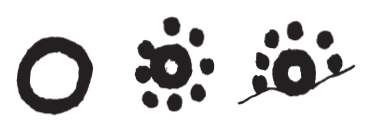

3
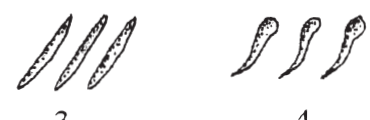

$\Rightarrow$

5

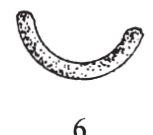

6 
el contrario, se va perdiendo con el tiempo; qué evolución ha experimentado el amplio repertorio compositivo que se conoce, etc. Coca ha aportado, y sigue aportando, interesantes datos para el pleno conocimiento de esta especialidad cerámica, pero ni son suficientes, ni definitivos, ni mucho menos incuestionables, por lo que no nos queda otro remedio que tenerlos como provisionales y esperar a que otros yacimientos amplíen, corrijan y maticen nuestros conocimientos actuales. Realmente, hasta ahora este grupo de grises se está contemplando por parte de la investigación fundamentalmente como marcador temporal, como referente de una cronología muy concreta para solucionar otros problemas, lo cual no es poco, pero no hemos de conformarnos sólo con esto.

Conectado con lo que al conocimiento de esta especialidad cerámica ha aportado Coca, otro de los aspectos que está pidiendo ser explicado es el de por qué en este yacimiento más que en ningún otro adquirieron tanta relevancia estas producciones. De momento, lo único que parece fuera de duda (por el volumen de materiales, variedad de tipos y calidades, presencia en todos sectores del yacimiento, abundancia de materias primas, existencia de una tradición alfarera, etc.) es que en él debieron de existir uno o varios alfares en los que se fabricaban como una especialidad vascular más, a pesar de que aún nos sean desconocidos. De la mano de este asunto viene otra cadena de interrogantes para la que por ahora tampoco tenemos respuestas: cesos intuidos alfares caucenses exportaron vasos grises a otros poblados?, de ser así ċa través de qué vías de distribución y a cambio de qué productos?, ¿con la hipotética comercialización de los mismos también se exportaron posibles funcionalidades específicas en caso de que las hubieran tenido algunos de ellos, como pudieran ser los caliciformes?, ¿fue destinatario de estos productos, tanto en Coca como en el resto de lugares en los que aparecen, algún sector social concreto o toda la comunidad?

Finalmente, aún está por esclarecer la cuestión del ocaso de estas producciones. Si bien sabemos de manera aproximada en qué momento se dejan de fabricar, desconocemos por completo las causas que determinaron su fin, aparentemente ocurrido en un lapso muy corto según algunos indicios, aunque de esto cada vez estamos menos seguros pues a la luz de lo que hoy sabemos para el caso concreto de Coca, y adelantándonos a las conclusiones, se puede decir que estos vasos siguieron estando en uso durante las décadas inmediatamente posteriores a que dejaran de producirse, penetrando con fuerza, por tanto, en la denominada "fase tardoceltibérica".

A pesar de que los señalados son sólo los más importantes, el listado de problemas que aún quedan por resolver para alcanzar una comprensión satisfactoria de este grupo de cerámicas celtibéricas es bastante mayor, conectados en muchos casos con otros campos de investigación y con otras áreas geográficas. Así, por citar muy rápidamente algunos a título de ejemplos pero en los que en esta ocasión no entraremos por no ser el objeto de este trabajo ya de por si algo extenso, es necesario explicar por qué esta especialidad cerámica apenas se documenta en la zona oriental de la Meseta, lo que nos conduce a pensar que estamos ante unas producciones genuinamente vacceas -por más que en algunos importantes núcleos adscribibles a esta etnia que han dado importantes colecciones cerámicas aún no se hayan documentado- pero que también fueron del gusto de los vettones. Asimismo, tarde o temprano habrá que entrar a valorar más en profundidad de lo que en su día hicimos las relaciones que pudieran haber existido entre las grises durienses y las de época tardía de los castros del noroeste peninsular y de la zona extremeña.

Está fuera de lugar en un trabajo de las características de éste tratar de aproximarnos a las respuestas a todos estos problemas, y aunque de forma tangencial toquemos muchos de ellos, nuestra intención es únicamente centrarnos en un par de aspectos. Por un lado, en algo tan básico como necesario en el estudio de materiales pero sobre el que habrán de apoyarse casi todos los que después vendrán: establecer un marco general de referencia morfológica, si bien provisional por ser aún pocas las formas completas de las que se dispone, en el cual ir encajando los repertorios locales. Por otro, nos interesa aproximarnos al problema de las influencias que sobre estas producciones ejercen otras familias y grupos cerámicos así como los recipientes argénteos. Pero antes de nada nos parece conveniente hacer una retrospectiva de cómo se ha desarrollado la investigación en este campo para tener claro en qué parte del proceso de estudio nos encontramos.

Tras una fase en la que los escasos vasos o fragmentos de cerámicas grises céreas que se van conociendo bien son incluidos, sin apenas especificación, en el corpus general de las celtibéricas finas del yacimiento en cuestión (p. ej., Cabré, Cabré y Molinero, 1950: lám. XIX, 10, 17, 23 y 27; Posac Mon, 1952: 69, fig. 3 1, 3, 4, 6 у 7; Molinero, 1971: 70, 2610, lám. CXV, fig. 1, 2610, 5-1; y los dudosos fragmentos de Picón y Castrojeriz: resp., Martín Valls, 1971: 133-134, fig. 3, 7, y Abásolo y Ruiz, 1976-77: fig. 2, 10.), bien 
simplemente son objeto de sumarias descripciones (Wattenberg Sanpere, 1959: 210-211, tab. XIV, $14^{1}$; Wattenberg García, 1978: 32, 45 y 58, forma XIV), en 1986 será Ángel Esparza el que, en el marco del estudio de los vasos de plata del tesoro I de Arrabalde que lleva a cabo para su obra sobre Los castros de la Edad del Hierro del Noroeste de Zamora, ponga en relación éstos con ciertas cerámicas grises de las que hasta el momento se conocían sólo unos pocos fragmentos procedentes de diversos yacimientos meseteños e intuya que nos encontramos ante una nueva especialidad cerámica celtibérica aún sin aislar y valorar por parte de la investigación (Esparza Arroyo, 1986: 263). Siguiendo las interpretaciones que algunos estudiosos lusos como Ferreira de Almeida o Alarçao hacen sobre las cerámicas grises tardías de los castros del norte de Portugal -quienes, a su vez, siguen la estela de arqueólogos anglosajones en los estudios que llevan a cabo sobre cerámicas muy similares que se documentan en las Islas Británicas-, en el sentido de las estrechas relaciones que presentan los vasos argénteos de tesoros como los de Chão de Lamas, Salvacañete o Tivisa, entre otros (Raddatz, 1969), y dichas cerámicas tanto desde el punto de vista formal como decorativo y en lo que a las cualidades cromáticas y táctiles se refiere-, Esparza se pronuncia en la misma dirección, hallándose, además, en su texto implícitas dos ideas que luego han resultado ser bastante acertadas: la cronología tardía de estas producciones y, en segundo lugar, su participación de la misma atmósfera de prestigio de la que gozaban los prototipos de plata, aunque este último rasgo hoy casi podemos decir que sólo afecta a determinadas formas de las doce que hasta ahora se conocen.

Al tiempo que esto escribía A. Esparza, en el yacimiento zamorano de La Dehesa de Morales (Fuentes de Ropel) se estaban desarrollando trabajos de prospección y varios sondeos, todo ello encaminado a establecer la geografía arqueológica de la zona, fijar la secuencia del enclave y contextualizar una serie de objetos conocidos de antiguo. Fue en la prospección del cenizal noroeste donde se recogieron unos pocos fragmentos de grises céreas que unos años más tarde daría a conocer, con dibujos incluidos, J. Celis

1. Como ya señalamos en otro lugar (Blanco García, 1993: 116), y a pesar de que se presta a otras interpretaciones, cabe la posibilidad de que ya en $1959 \mathrm{~F}$. Wattenberg advirtiera la existencia de este peculiar grupo de cerámicas celtibéricas al manifestar la presencia en territorio vacceo de “...otros vasos negruzcos que se decoran con estampillas, estando torneados y
(1990: 473-474 y 489, fig. 9, 5-12). En los párrafos que a las mismas dedica el referido autor, además de describir sus características básicas en cuanto a los aspectos técnicos, formales y decorativos -lo cual constituye un paso más en la definición del grupo-, y ampliar la nómina de yacimientos meseteños en los que se documentan al añadir Gorrita, 'La Ciudad' de Paredes de Nava y Pinilla Trasmonte, se muestra partícipe de la idea de Esparza en cuanto a la relación que parecen tener estas producciones con la vajilla de plata de los siglos II y I a. C., llamando al mismo tiempo la atención sobre la raigambre cogotiana de algunos de los elementos decorativos.

Por pura y simple coincidencia, en el año 1993 se publicaron diversos trabajos referidos a dos complejos arqueológicos como son Padilla/Pesquera de Duero y Coca que, a la postre, conducirían a este singular grupo de cerámicas celtibéricas a alcanzar su "mayoría de edad", si se nos permite la expresión, desde el punto de vista de la investigación. Por una parte, C. Sanz, A. Gómez y J. A. Arranz daban a conocer tres caliciformes completos obtenidos en la Tumba 1 de la necrópolis vallisoletana de Carralaceña (Sanz Mínguez, Gómez Pérez y Arranz Mínguez, 1993: 132, M, N y O y 142-144, fig. 2, M, N y O) y un cuarto ejemplar incompleto del que se desconoce la sepultura de la que procede (Id., 1993: 134, G y fig. 3, G). En el epígrafe que les dedican comienzan por dar unas notas técnico-descriptivas del tipo cerámico en cuestión y tras hacer un repaso de los precedentes existentes en el discernimiento de esta especialidad vascular celtibérica y referir además de los hallazgos citados por Esparza y Celis algunos otros como el de Segovia capital, publicado de antiguo, o el palentino del tesoro de Las Filipenses, éste inédito, abordan una serie de aspectos tan interesantes como son las influencias que en él se dan cita, la corta y precisa cronología que parecen tener, su carácter de productos locales y la posible funcionalidad que pudieron haber tenido. Respecto a la primera cuestión, de nuevo se incide en lo que los vasos de plata y las cerámicas a mano y a torno grises estampadas de Cogotas II debieron de contribuir en el nacimiento de tan peculiares vasos, añadiendo los citados autores algo tan evidente como

presentando formas tardías". (Wattenberg Sanpere, 1959: 177). Lo que es de indudable atribución a este investigador es el haber señalado en aquella ocasión uno de los rasgos más característicos que poseen estas cerámicas: el tacto céreo de sus superficies bruñidas (Id., 1959: 210, tab. XIV, 14) 
que también la clásica cerámica oxidante pintada debió de ejercer cierto influjo.

A falta de referencias de cronología absoluta obtenidas por métodos físico-químicos para el conjunto analizado, la propuesta de llevar estos productos a momentos sertorianos, anteriores, por tanto, a la formación de los denominados conjuntos tardoceltibéricos (mediados del I a. C.), se realiza cruzando informaciones relativamente fiables de diversos yacimientos como son los perfiles cronológicos que ofrecen tanto los vasos pintados que comparten contexto con las piezas de Carralaceña como aquellos que lo hacen con el vaso de Tariego, la fecha aproximada que se estima para la ocultación de Las Filipenses o la sugerida para el abandono de Pinilla Trasmonte. No obstante, al admitir la posibilidad de que los fragmentos de La Mesa de Miranda pudieran remontarse hasta mediados del II a. C., en virtud de que los materiales más modernos no parecen alcanzar el siglo I a. C. y los prototipos argénteos ya estuvieron en uso a lo largo de la segunda centuria, se deja una puerta abierta a que en algún caso pudieran ser algo más antiguos. Paralelamente a esta acertada observación, en Coca estábamos llegando a las mismas conclusiones pues, como más adelante veremos, a partir de los datos obtenidos en las excavaciones que venían practicándose desde 1987 se podía también decir que, efectivamente, los momentos iniciales de este grupo cerámico había que llevarlos hacia el 130/125 a. C., a unos momentos posteriores al asalto de Lúculo del 151 a. C. pero cercanos al paso por Coca de P. Cornelio Escipión Emiliano en 134 a. C.

Un tercer aspecto que en el citado trabajo se recoge como novedoso es el del más que probable carácter local de estos productos padillenses. Basándose en que cada vez son más numerosos los ejemplares conocidos en el yacimiento y en el hallazgo de algún fragmento en las proximidades del horno de Carralaceña, Sanz, Gómez y Arranz intuyen que fueron fabricados en el lugar. Fuese o no así, y aún faltando pruebas definitivas y concluyentes al respecto, nosotros también estamos convencidos de que si hay dos núcleos poblacionales vacceos en los que hoy día se pueda decir casi con total seguridad que existió producción de vasos grises céreos esos son Padilla/Pesquera de Duero y Coca.

Finalmente, siguiendo las pistas que ofrecen tanto los simpula como los caliciformes grises de las cuevas santuario ibéricas, aunque de nuevo sin evidencias directas y concluyentes que lo demuestren, sugieren la posibilidad de que los tres vasos vallisoletanos pudieran haber sido recipientes para ser usados en actos especiales de carácter simbólico/cultual.
Un dato más que contribuye al esclarecimiento de este grupo cerámico es aportado por A. Gómez y C. Sanz en el trabajo que sobre la secuencia estratigráfica del poblado de Las Quintanas escriben para el volumen de Arqueología Vaccea publicado ese mismo año 1993: los caliciformes grises a torno presuntamente de época sertoriana pudieron tener como prototipos no sólo los vasos de plata sino también ciertas producciones manuales de superficies lustrosas que, a su vez, también son posibles imitaciones de piezas metálicas. La recuperación en el citado poblado de un vaso hecho a mano, bruñido, con cuatro asas y decoración en todo similar a la que encontramos en los caliciformes grises, pero en un nivel (III) estimado como inmediatamente anterior al inicio del siglo I a. C., les lleva a pensar que quizá vasos como éste estén marcando la antesala de sus homólogos torneados (Gómez Pérez y Sanz Mínguez, 1993: 358-360, fig. 11, 3). Participando por nuestra parte de tan sugestiva propuesta, máxime cuando se sustenta en argumentos estratigráficos, en ella no se valora una posibilidad que nos parece viable y del todo compatible: que los primeros grises hechos a torno hubieran sido fabricados al tiempo que lo estaban siendo estos vasos manuales.

Simultáneamente a la publicación de estos novedosos datos sobre los recipientes de Padilla/Pesquera de Duero, también nosotros dábamos a conocer en dos artículos aquellos que en diversas excavaciones de Coca habían sido exhumados entre 1987 y 1990. El primero de ellos tenía por objeto ofrecer los resultados preliminares de un sondeo practicado en la Avda. de la Constitución (hoy n. 8), por lo que nos limitamos a presentar fragmentos pertenecientes a tres de estas piezas grises y unas pocas notas explicativas de carácter general referentes a las características técnicas, cronología y dispersión geográfica de estas producciones (Blanco García, 1993a: 164, fig. 7, 9-11) que tomamos del segundo de los artículos, escrito algo antes que éste pero publicado al mismo tiempo.

Este segundo trabajo, el primero que con carácter monográfico se le ha dedicado hasta ahora a este grupo cerámico de la familia celtibérica (Blanco García, 1993b), fue elaborado para cumplir varios objetivos. En primer lugar, para dar a conocer el ya voluminoso conjunto que entre los años arriba indicados se había ido formando en Coca como consecuencia de la excavación de numerosos sondeos $\mathrm{y}$, de paso, tratar de atraer la atención de la investigación hacia esta especialidad cerámica tan escasamente constatada en importantes yacimientos meseteños como particularmente abundante en el enclave segoviano. 
Como es lógico, estrechamente ligado a esto estaba nuestra intención de aproximarnos a la definición y sistematización, en todos sus parámetros, de tan peculiares productos y con ello integrarlos en el lugar que les correspondiese dentro del panorama general peninsular de las cerámicas grises a torno protohistóricas. Recordado ese panorama general y expuestas las características técnicas de las cerámicas en cuestión, pudimos ya introducirnos en los aspectos más novedosos e interesantes. Así, frente a las escasísimas y fragmentarias formas que hasta entonces habían sido documentadas en poco más de media docena de yacimientos meseteños -prácticamente las de cáliz, algún perfil en "s" y paredes verticales-, el lote de Coca mostraba cierta riqueza de formas que agrupamos en nueve tipos principales, algunos de los cuales contaban con variantes. Esto supuso poner sobre la mesa el repertorio tipológico básico del grupo, que con el tiempo habría que ir ampliando, pero del que al menos tres ideas se podían ya apuntar: que estábamos ante un repertorio más restringido que el conocido para las cerámicas finas oxidantes, que, con mayor o menor fidelidad, todas las formas grises contaban con homólogas anaranjadas y, en tercer lugar, que tras este abanico de formas debió de existir, lógicamente, una diversidad de funciones relacionada fundamentalmente con la mesa y la guarda de productos de calidad. Es decir, que no estábamos ante un producto creado exclusivamente para cubrir una única función como pudiera pensarse de sus especiales características técnicas con las que parecen querer participar de la atmósfera de prestigio que debió de envolver a los vasos metálicos. Al hilo de esto último, y aunque al parecer quizá no insistimos lo suficiente, señalamos la idea de que al menos ciertas formas como las de cáliz, las copas y algunas urnas probablemente estuvieran emulando recipientes de plata de tesoros peninsulares bien conocidos de los siglos II y I a. C., mostrando de este modo nuestro total acuerdo con lo dicho por autores que nos habían precedido en el estudio de estos vasos (Blanco García, 1993b: 123 y 132). Además, en este grupo cerámico tomado en su conjunto se daban cita influencias de amplio espectro que iban más allá de las aportadas por tales recipientes. Influencias de las finas oxidantes, de las peinadas tradicionalmente conocidas como de Cogotas II, tanto en lo que se refiere a determinadas formas como a tratamientos superficiales y recursos decorativos (Blanco García, 1993b: 115, 130 y 132), y de la vajilla campaniense (Blanco García, 1993b: 118, 127 y 134), a pesar de la escasa presencia que muestra ésta en el Valle del Duero (Martín Valls y Esparza Arroyo, 1992: 272).
El último dato de interés que en este trabajo pudimos ofrecer fue el de los umbrales cronológicos aproximativos entre los que se extendía la producción de estos vasos grises en Coca a partir de la comparación de varias secuencias estratigráficas: último tercio del siglo II a. C. y primer cuarto del I. En este sentido, nos pareció que aún era prematuro entrar en el problema de las pervivencias, aspecto sobre el que en esta ocasión algo podremos decir, afortunadamente, gracias a la información obtenida en las últimas campañas de excavación en Coca.

El súbito interés despertado por estas producciones a raíz de las recientes excavaciones en Padilla/Pesquera de Duero y Coca, condujo a Delibes, Romero, Sanz, Escudero y San Miguel (1995: 110-111) a escribir un resumen de cuanto se sabía sobre las mismas hasta ese momento dentro del panorama general que para el volumen de Arqueología y Medio Ambiente elaboran sobre la Edad del Hierro en el Duero Medio, con lo cual se puede decir que este minoritario y peculiar grupo cerámico se incorpora a los trabajos panorámicos sobre la cultura celtibérica como una parcela más de estudio. Por otra parte, la ocasión es aprovechada para llamar la atención sobre un tipo de cerámicas negras muy bruñidas que se decoran, a su vez, con trazos bruñidos y finas incisiones, afines a las grises céreas y de presumible cronología similar, que sólo parecen constatarse por ahora en Padilla y Cuéllar.

Un apunte más, en este caso relativo a la presencia de estas cerámicas en algunos yacimientos celtibéricos leoneses, da Celis Sánchez en el capítulo que sobre la Edad del Hierro en esta provincia escribe para las actas de Historia de León a través de la Arqueología (Celis Sánchez, 1996). Aunque no se dan referencias concretas salvo para un probable fragmento de Valle de Mansilla, este autor parece querer dar a entender que en el Valle del Esla existen varios yacimientos más en los que se tienen constatadas “...cerámicas grises a torno, con acabados y decoraciones que imitan a vasos argénteos, tal y como se han descrito en La Dehesa de Morales, Padilla de Duero o Coca, etc." (Celis Sánchez, 1996: 58, fig. $5,11)$, lo cual supone la ampliación de este grupo cerámico hacia el noroeste del espacio meseteño y reabre la cuestión de las posibles conexiones entre estas producciones y las grises estampadas del área gallega y norte de Portugal.

Las últimas páginas escritas sobre este peculiar grupo cerámico se deben de nuevo a C. Sanz Mínguez, quien en su Tesis Doctoral sobre la necrópolis de Las Ruedas les dedica un epígrafe a propósito de la recuperación de nuevos materiales (Sanz Mínguez, 1997: 162-164 nn. 300-321, 


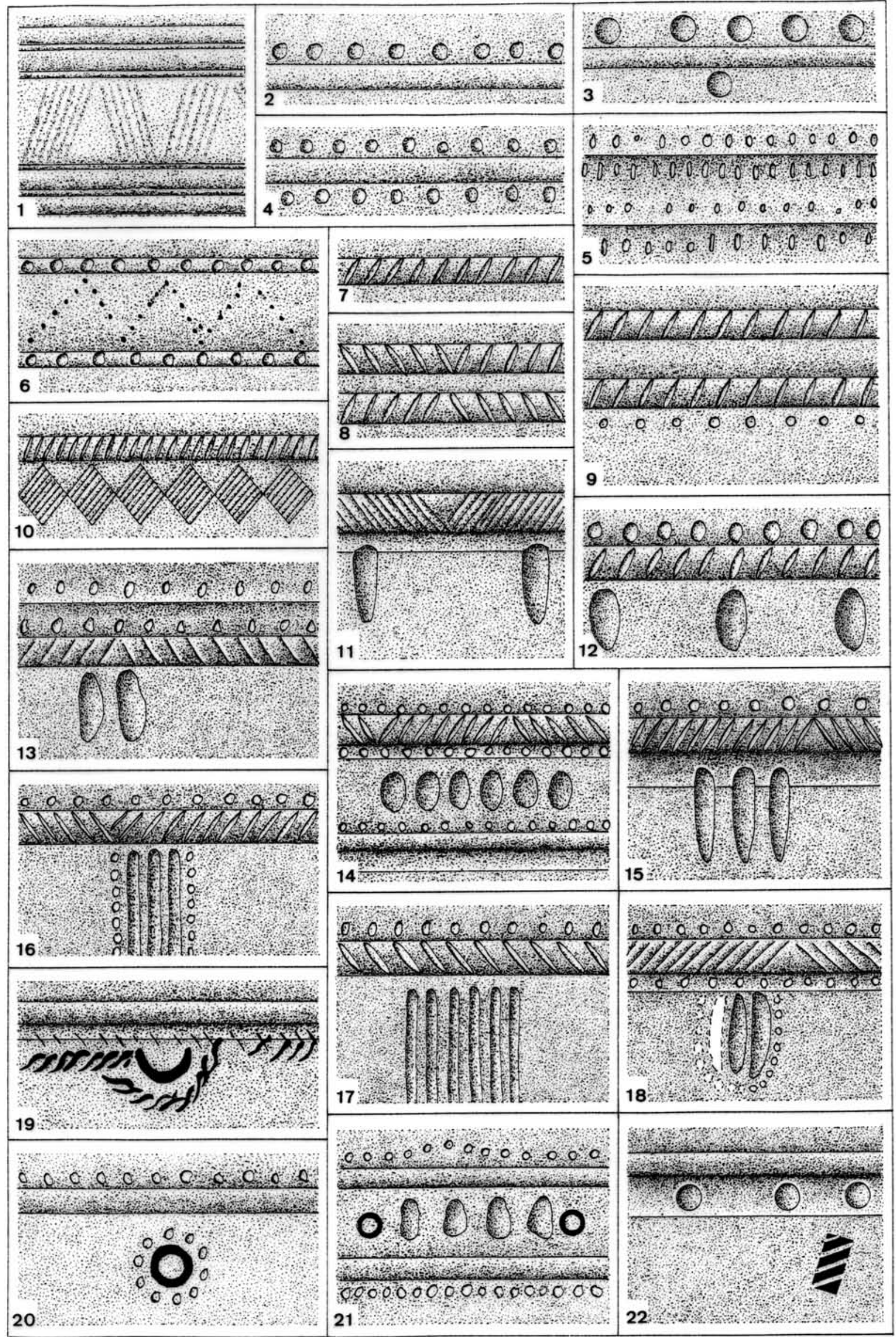

Figura 4.- Tabla de composiciones decorativas 


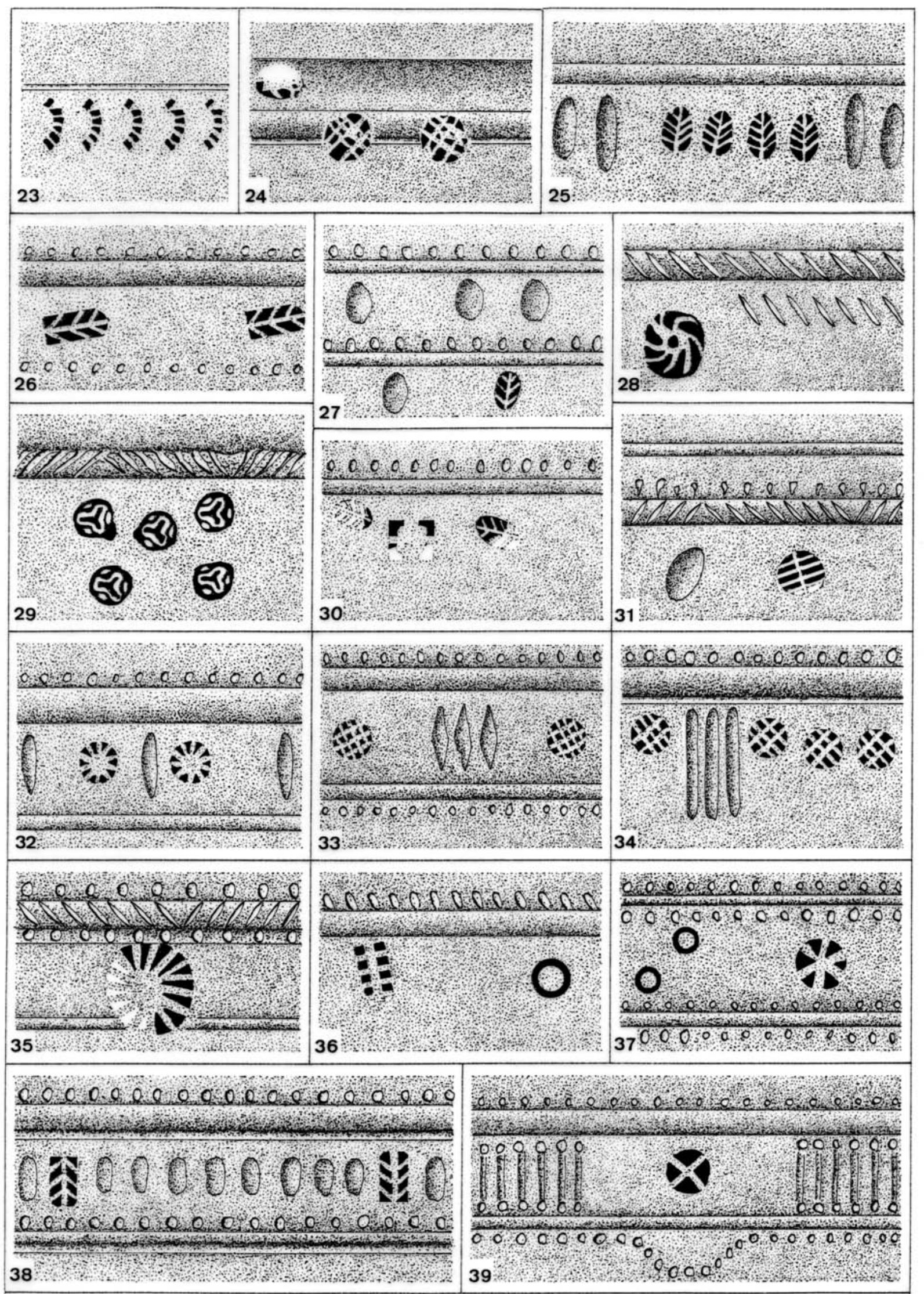

Figura 5.- Tabla de composiciones decorativas (cont.). 


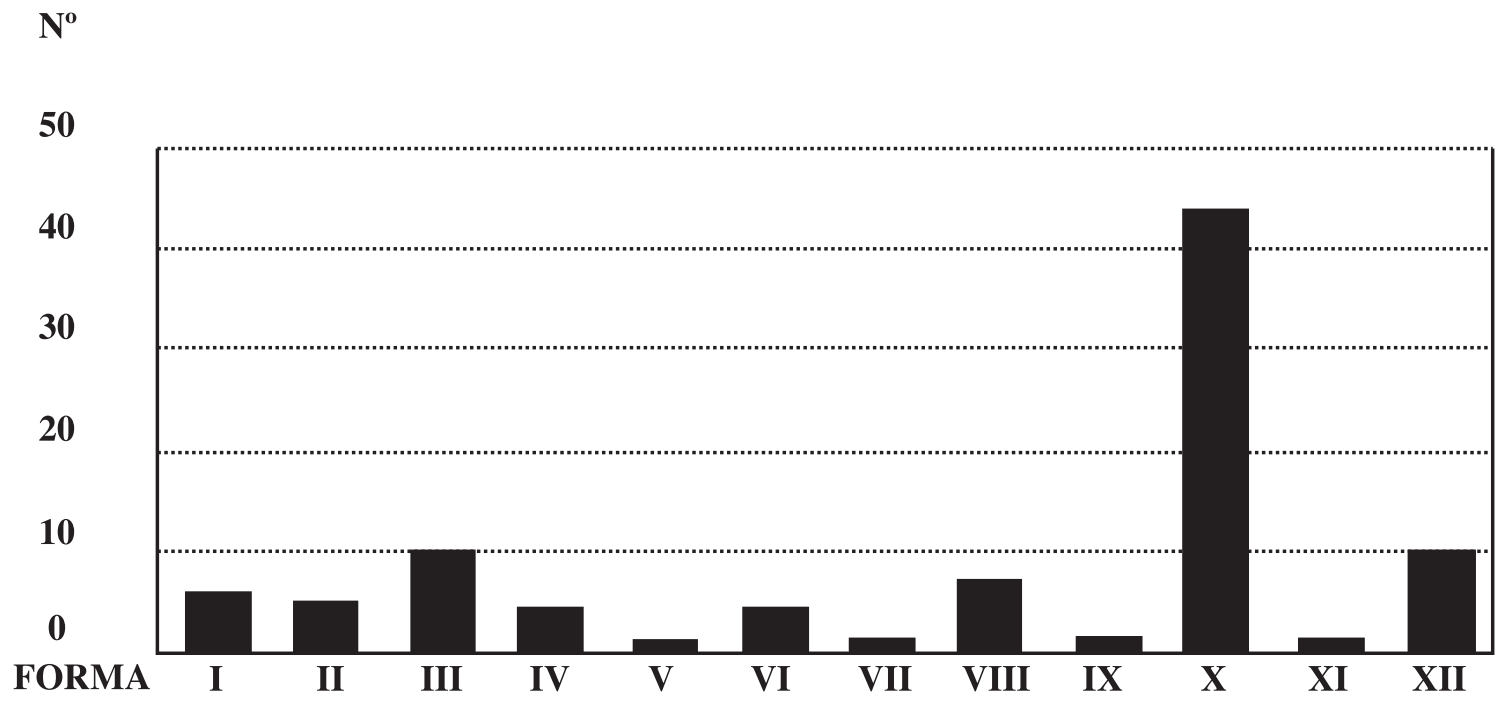

Figura 6.- Cuadro comparativo de las formas, en cifras absolutas.

309-312, fig. 161), a los que añade los ya conocidos caliciformes de Carralaceña (Sanz Mínguez, 1997: 42-43 y 309, fig. 11, M, N y O, y fig. XXVI). Desafortunadamente, por encontrarse aquéllos en su mayor parte en posición secundaria (salvo el vaso $\mathrm{H}$ de la tumba 3: 54, fig. 20), la posibilidad de haber podido comparar sus contextos con los de los vasos caucenses queda practicamente anulada, reduciéndose su interés a las piezas per se y a la información cronológica que propician sobre las zonas concretas del cementerio en las que se hallaron (sectores $\mathrm{AK}$ a $\mathrm{AQ}$ de la Zanja II y Zanja III).

Nada tiene de extraño que el repertorio de formas sea más restringido que el de Coca, pues el vallisoletano es un conjunto sensiblemente menos numeroso que el segoviano. $\mathrm{Y}$, sin embargo, en él se constatan tres nuevas, a decir de Sanz, aunque a nuestro entender realmente sólo cabe considerar como nueva una, el oinochoe n. 319 , pues las otras dos, el vaso de perfil en " $\mathrm{s}$ " $\mathrm{n}$. 318 y la urna con cuello alto suavemente invasado y carena baja n. 317, se pueden considerar como varientes de tipos ya conocidos. Se sorprende Sanz de que en Las Ruedas no comparezcan los platos, fuentes, cuencos y morteros, tan bien representados en Coca. A nosotros no nos parece tan extraño el hecho, pues consideramos, por una parte, que, salvo los cuencos, tales formas sólo están presentes cuando se trata de lotes numerosos como el caucense, característica de la que no es partícipe el conjunto padillense, $y$, por otra, que, a pesar de que en las necrópolis no suelen faltar, son tipos cerámicos más propios de ambientes domésticos que funerarios, y recordemos que la colección segoviana se recuperó íntegramente en contextos habitacionales. No hay más que echar una ojeada, sin ir más lejos, al repertorio formal de vasos torneados oxidantes del mismo cementerio de Las Ruedas para comprobar cómo, si bien los cuencos tienen una presencia destacada, sólo se constatan una fuente (Sanz Mínguez, 1997: 120, L, fig. 118, L, y forma I), algunos vasos-soporte que perfectamente podrían pasar por platos o fuentes (Sanz Mínguez, 1997: 67, F, fig. 50, F, y 154 n. 209, fig. 154 n 209, p. ej.) y un único mortero (Sanz Mínguez, 1997: 148 n. 150, fig. 151 n. 150, y 287, forma VII 2, fig. 211, VII 2), tipos todos ellos numéricamente bien representados en Coca.

Tras hacer un repaso de los conocidos yacimientos en los que comparece esta especialidad cerámica y reafirmar el marco cronológico en el que ha sido encuadrada, termina Sanz insistiendo en el carácter lujoso y simbólico de los mismos, rasgo este último deducido a partir de las posibles relaciones que pudieran guardar tanto con los simpula como con los vasos grises de las cuevas-santuario ibéricas. Tampoco a nosotros nos caben muchas dudas respecto al carácter lujoso que estos vasos grises tuvieron dentro del elenco de productos cerámicos en uso, pero no estamos tan seguros de que a todo el conjunto, a todo el grupo, haya que aplicar perfiles ideológicos. Los caliciformes y las urnas posiblemente tuvieran usos especiales puesto que son las únicas formas por ahora presentes en ambientes cargados de simbolismo mágico-religioso (funerarios o no), pero en todo caso éstos no fueron sus funciones exclusivas, sino unas más, del mismo modo a como ocurre con las cerámicas oxidantes, presentes siempre en los conjuntos funera- 
rios. El contrapunto al perfil "trascendentalista" que para estas dos formas representan las necrópolis de Carralaceña y Las Ruedas lo pone Coca con sus decenas de ejemplares amortizados en ambientes domésticos tras mucho tiempo de haber estado en uso, como indican las numerosas rozaduras y golpes que casi todos muestran. Para el resto de formas -platos, boles, copas, morteros, etc.-, la idea de que encerraran connotaciones simbólicas no parece de aplicación. El problema es difícil de solucionar con la documentación hasta ahora disponible, por lo que no nos queda otro remedio que esperar a que se generen nuevos y clarificadores datos al respecto.

\section{FORMAS Y DECORACIONES}

En la aproximación tipológica que para el conjunto caucense llevamos a cabo en 1993 pusimos de manifiesto cómo, a pesar de haber reunido un importante volumen de materiales, el repertorio formal era ciertamente escaso. Muchos de los tipos que habitualmente encontrábamos en cerámica de cocción oxidante tanto en Coca como en el resto de yacimientos del Duero Medio no se constataban en pastas grises y negras de superficies céreas. Estaban ausentes y lo siguen estando- formas como las botellas de boca de seta, las jarras de boca circular y cuerpos cilíndricos, bulbosos o globulares, las de tipo "bock", los kalathoi, las tazas acampanadas, los embudos, las cantimploras, etc., y, por supuesto, las voluminosas para uso de almacén. Tampoco conocemos, por ahora, tapaderas, pero seguramente porque nunca se fabricaron, pues en ninguno de los bordes de los treinta y cuatro perfiles discernidos existe acondicionamiento alguno para la adaptación de las mismas. La poca atención de la que habían sido objeto estas cerámicas por parte de la investigación nos hizo suponer que a medida que ésta se fijara en ellas se darían a conocer nuevos conjuntos recuperados en otros yacimientos meseteños y, con ellos, nuevas formas con las que poco a poco ir completando la tipología del grupo. Sin embargo, trancurrida una docena de años, en poco se han incrementado aquellas nueve formas básicas que se indivi-

2. Ya en estos momentos hay fragmentos a los que resulta difícil encontrar acomodo en la tipología de formas y variantes que proponemos debido a su singularidad, lo que quiere decir que tarde o temprano irán apareciendo nuevos perfiles con los que éstos encajen plenamente. Tal es el caso, p. ej., de un fragmento de la Dehesa de Morales (Celis Sánchez, 1990; 473-474., fig. $9,11)$ que podría pertenecer tanto a alguna urna de paredes verticales como a una jarra de tipo "bock" o a dualizaron en Coca, a pesar de lo cual creemos que es un margen temporal prudente y ya va siendo necesario dar un paso adelante más intentando llevar a cabo una sistematización formal, eso sí, provisional, que abarque el conjunto del Valle del Duero, para con ello empezar a concretar lo mejor que se pueda todo cuanto se refiere a las variantes que cada tipo presenta. Como es de esperar que a medio y largo plazo habrá que ir sumando nuevas formas y variantes, en las páginas que siguen hemos tratado de crear una tipología abierta, de manera que incluso aquellas que están representadas por un único vaso (Formas V, VII, IX y XI) éste ha sido individualizado por medio del segundo dígito en numeración arábiga como todas las demás ${ }^{2}$.

Generalmente no existen muchas complicaciones llegado el momento de organizar por tipos morfo-funcionales los recipientes cerámicos de un yacimiento o conjunto de yacimientos. El primer problema se plantea desde el momento en que una parte del material no se ha conservado en todo su perfil, de la boca al centro radial de la base, y la adscripción tipológica queda, por tanto, incompleta. En nuestro caso esto tiene especial incidencia por cuanto de los treinta y cuatro perfiles discernidos -agrupados en doce formas generales-, sólo seis están completos (II 3, III 1-3 y X 1 y 2), de tres más se puede decir que prácticamente también lo están aunque les falte una pequeña parte (I 3, VIII 2 y XI 1), y los veinticinco restantes son fragmentarios. El segundo escollo lo encontramos cuando dentro de un tipo tratamos de establecer los subtipos y variantes a base de ir agrupando las múltiples y a veces poco significativas variaciones morfológicas en unos cuantos perfiles representativos que engloben todo el espectro formal. Tres son las causas que pueden dar origen a subtipos o variantes dentro de una misma forma: la modificación inintencionada y puramente accidental que en la reproducción de una forma provoca el alfarero como consecuencia de que en todo trabajo manual nunca dos piezas son absolutamente idénticas, la incorporación paulatina e intencionada de pequeñas variaciones que poco a poco van transformando el modelo original y con el tiempo traen consigo

alguna de las formas consideradas por Sacristán como raras (1986: 179, lám. LI, 6), en todo caso tipos siempre conocidos en arcillas anaranjadas. Lo mismo cabe decir respecto a un desarrollado pie adornado con calados sobre baquetón (Pérez González y Blanco García, 2000: fot. inf. de p. 39) del que no podemos decir si perteneció a un crateriforme, a una copa (con lo que estaríamos ante un fuste calado) o bien se trata de un soporte exento. 
la creación de un tipo nuevo ya distante del inicial y, en tercer lugar, la alteración parcial de la forma por parte del alfarero para adaptarla a una función algo diferente a la que tenía que atender el modelo primitivo. De las tres, las dos últimas tienen evidentes connotaciones cronológicas pero como desconocemos la secuencia de los eslabones de la cadena, qué tipos son los iniciales y cuáles los intermedios y terminales, no hay más alternativa que ordenar los subtipos y variantes de los repertorios conforme a criterios subjetivos. Por ello, más que construir una auténtica y sólida tipología de las grises de imitación metálica, lo que pretendemos en el desglose formal que sigue es ir aislando formas y variantes dentro de ellas tomando como referencia los prototipos que en pastas rojas y anaranjadas se venían fabricando desde décadas anteriores-, de manera que este trabajo sirva para la elaboración futura de esa consistente y más o menos definitiva tipología.

Para que sea útil una tipología cerámica (o de cualquier otro utensilio), cada tipo, subtipo o variante debería llevar asociado una cronología. Sin embargo, en el caso concreto del grupo vascular aquí ordenado este es un aspecto al que, por falta de microsecuencias estratigráficas que abarquen toda la vida de estas cerámicas en los yacimientos, nos vemos obligados a renunciar, englobando el conjunto entre los años 130/125 y el 75/70 a. C. Este último parece ser el umbral cronológico en el que termina de fabricarse esta especialidad cerámica pero el de su uso, imposible de determinar con cierta exactitud, hay que llevarlo al menos hasta bien entrada la segunda mitad del siglo I a. C., como más adelante trataremos de demostrar a partir de nuevos datos generados en las últimas excavaciones de Coca. Por otro lado, estamos comenzando a ver que los caliciformes constituyen una de las formas que primero se produjeron y más perduraron, o que las fuentes, copas y pies calados siguieron en uso a lo largo de buena parte del siglo I a. C., pero los argumentos demostrativos que manejamos son aún algo endebles por proceder exclusivamente de Coca y no poderlos contrastar con

3. Iguales o semejantes, ninguno de los tres signos hasta ahora constatadas en cerámica gris cérea es nuevo en objetos cerámicos o metálicos celtibéricos e incluso romanos. Así, el designado como 6.1 lo encontramos, p. ej., en un vaso a torno de Las Cogotas (Cabré Aguiló, 1930: 77, fig. 8, 3), en una urna de la sepultura 1256 de La Osera (inédita), dobles pero en simetría contrapuesta en vasos del poblado de El Raso de Candeleda (Fernández Gómez, 1986: figs. 134, 232, 235 y 464, 1, B439 y C394), sobre pesas de telar de Langa de Duero (Taracena, 1929: 42 fig. 24), etc. Más corriente aún son las grafías en forma de flecha (tipo 6.2) que pueden estar representando el sonido ibérico estratigrafías obtenidas en otros lugares, aunque en Padilla/Pesquera de Duero hay indicios que apuntan en la misma dirección.

\section{Forma I: plato (Fig. 1).}

Viene constituida por recipientes en los que la anchura duplica o triplica la altura (índice 6,19 para el único ejemplar del que se puede obtener: el I 3), que cuentan con bordes amplios en voladizo suavemente curvados a veces partiendo de una carena, paredes tendidas más o menos curvadas y fondos casi planos al interior pero ligeramente rehundidos o anulares bajos al exterior. Es una forma de la que en estas producciones grises constatamos por ahora nada menos que cinco variantes, aunque ninguna conservada en todo su perfil. Aparte de las que acabamos de señalar, como características comunes a todas ellas están la de haber recibido excelentes bruñidos tanto por dentro como por fuera $y$, salvo en un caso cuyo diámetro desconocemos (I 4), tener un tamaño pequeño. Realmente son platitos de entre 8,8 y $15,4 \mathrm{~cm}$ de diámetro que nos plantean el interrogante de la funcionalidad que pudieron haber tenido, pues no parecen unas dimensiones muy adecuadas para tomar alimentos.

Ninguno de los platos que hasta ahora conocemos porta decoración alguna, por lo que se puede decir que esta es una forma lisa, ya que en absoluto se podrían considerar como elementos decorativos las carenas o los pares de orificios para la suspensión, tan habituales en los recipientes de esta morfología. Si acaso, la acanaladura del borde de la primera de las variantes que vamos a referir podría tener la consideración de elemento decorativo. Lo que sí encontramos en alguno de estos pequeños platos, y que también son corrientes en sus iguales oxidantes, son los grafitos, posibles marcas de alfarero o del propietario del recipiente localizados bien en el fondo bien en la pared pero siempre por el exterior (Fig. 3, grupo 6, 1 y 2, también recogido este último en Blanco García, 1994: 60, fig. 15, 1), y lógicamente considerados en la Meseta como elementos indicativos de modernidad $^{3}$, pues en

"u", pues nos consta, entre otros, de nuevo en Las Cogotas (Cabré Aguiló, 1930: 77, fig. 8, 4), en Numancia (Arlegui Sánchez, 1992: 482, lám. 3, 22), etc.. Menos habituales que las anteriores son las marcas formadas por dos líneas paralelas y una tercera que las cruza (tipo 6.3), aunque en Coca ya conocíamos una casi igual pero grabada antes de la cochura en un borde de cerámica común celtibérica, en Cerro Redondo comparece también en vasos grises bruñidos más antiguos que los del Duero (Blasco y Alonso, 1985: 106, fig. 37, 8) y en Las Quintanas de Padilla de nuevo aparece en un caliciforme pintado (Gómez Pérez y Sanz Mínguez, 1993: 367, fig. 16, 7). 


\begin{tabular}{|c|c|c|c|c|c|c|}
\hline $\begin{array}{l}\text { Excav. } \\
\text { Nivel }\end{array}$ & T.M. I & T.M. II & T.M. III & $\begin{array}{l}\text { C/Azafra- } \\
\text { nales n. } 5\end{array}$ & $\begin{array}{l}\text { Convento } \\
\text { II }\end{array}$ & $\begin{array}{c}\text { Avda. de la } \\
\text { Constitución n. } 8\end{array}$ \\
\hline \multicolumn{7}{|l|}{$\mathrm{I}$} \\
\hline \multicolumn{7}{|l|}{ II } \\
\hline \multicolumn{7}{|l|}{ III } \\
\hline \multicolumn{7}{|l|}{ III } \\
\hline \multicolumn{7}{|l|}{ IV } \\
\hline $\mathrm{V}$ & $\begin{array}{l}3 \mathrm{cg}, 7 \text { cap } \\
\text { y } 2 \mathrm{pb}\end{array}$ & & $\begin{array}{l}5 \text { fragts. cg y } \\
2 \text { pb y TSG }\end{array}$ & & & \\
\hline VI & $\begin{array}{l}\text { destrucción } \\
\text { de hacia el } \\
50 \text { a. C. }\end{array}$ & & $\begin{array}{l}31 \text { fragts. de } \\
\mathrm{cg}, \mathrm{b}, \mathrm{c}, \text { ind, } \\
4 \text { cap y } 7 \text { pb }\end{array}$ & & & \\
\hline VII & & & $1 \mathrm{cg} \mathrm{y} 4$ ind & & & \\
\hline VIII & & & 1 ind & & & \\
\hline IX & & & & $\begin{array}{l}\text { Ya con TSI, } \\
\text { TSG y TSH } \\
\end{array}$ & & \\
\hline $\mathrm{X}$ & $\begin{array}{l}1 \mathrm{cg}, 1 \mathrm{p}, 2 \\
\mathrm{ba}, 5 \text { cap y } 1 \\
\mathrm{pb}\end{array}$ & & & & & \\
\hline XI & 2 cap & & & $\begin{array}{l}1 \mathrm{~s}, 1 \mathrm{ba}, 1 \\
\text { cap y } 1 \mathrm{pb}\end{array}$ & & \\
\hline XII & & & & $\begin{array}{l}3 \text { ind } 2 \text { cap } \\
\text { y } 11 \mathrm{pb}\end{array}$ & & \\
\hline XIII & & Ya con TS & & 1 cap & & \\
\hline XIV & & $\begin{array}{l}2 \mathrm{cg}, 1 \text { cap } \\
\text { y } 2 \mathrm{pb}\end{array}$ & & $\begin{array}{l}\text { ¿destrucción } \\
\text { del } 74 \text { a. C.? }\end{array}$ & & Ya con TS \\
\hline XV & & $1 \mathrm{cg}$ & & $\begin{array}{l}3 \mathrm{cg}, 1 \mathrm{~b}, 3 \\
\mathrm{ba}, 4 \text { ind, } 3 \\
\text { cap y } 2 \text { pb }\end{array}$ & & $\begin{array}{l}1 \mathrm{~m} \\
\text { ¿destrucción del } 74 \\
\text { a. C.? }\end{array}$ \\
\hline XVI & & & & & & $\begin{array}{l}4 \mathrm{cg}, 1 \mathrm{f}, 1 \mathrm{cu}, 1 \mathrm{~b}, 5 \\
\mathrm{ba}, 4 \text { ind y } 4 \text { cap }\end{array}$ \\
\hline XVII & & 1 cap & & $\begin{array}{l}4 \mathrm{cg}, 1 \mathrm{~m}, 5 \\
\text { ind y } 2 \text { cap }\end{array}$ & & \\
\hline XVIII & & & & $\begin{array}{l}6 \mathrm{cg}, 1 \mathrm{p}, 1 \mathrm{c}, \\
1 \mathrm{u}, 1 \text { cap y } \\
\text { C.II }\end{array}$ & & C.II y caja excisa \\
\hline \multicolumn{7}{|l|}{ XIX } \\
\hline $\mathrm{XX}$ & & & & ¿destrucción & $\begin{array}{l}2 \text { cap, } 1 \mathrm{pb}, \\
\text { TS y pp. finas }\end{array}$ & \\
\hline XXI & & & & $\begin{array}{l}\text { del } 151 \text { a. C.? } \\
1 \text { ind intru- } \\
\text { sivo y C.II }\end{array}$ & $2 \operatorname{cg}$ y 3 ind & \\
\hline XXII & & & & & $\begin{array}{l}3 \mathrm{cg}, 2 \mathrm{c}, 2 \mathrm{~s}, \\
1 \mathrm{ba}, 2 \text { ind, } 6 \\
\text { cap y } 1 \text { cae }\end{array}$ & \\
\hline \multicolumn{7}{|l|}{ XXIII } \\
\hline \multicolumn{7}{|l|}{ XXIV } \\
\hline XXV & & & & 1 cap y C.II & & \\
\hline
\end{tabular}

Figura 7.- Asociaciones significativas de materiales cerámicos en las estratigrafías de Coca. Código: T.M.= Tierra de las Monedas; $p=$ plato; $f=$ fuente; $c=$ cuenco/copa; $m=$ mortero; $c u=$ cubilete; $b=b o l ; e=$ esferoide; $s=$ perfil en " $\mathrm{S}$ "; $c g=$ caliciforme gris; $c a(p)=$ caliciforme anaranjado (pintado); cae = caliciforme anaranjado estampado; $c r=$ crateriforme; $u=u r n a ; b a=b a s e ; p b=$ fragto. anaranjado con pintura blanca; ind= forma indeterminada; C.II= a mano de Cogotas II. (Salvo los cap, cae y pb, lo demás se refiere a vasos grises de imitación metálica). (En gris, nivel de incendio). 


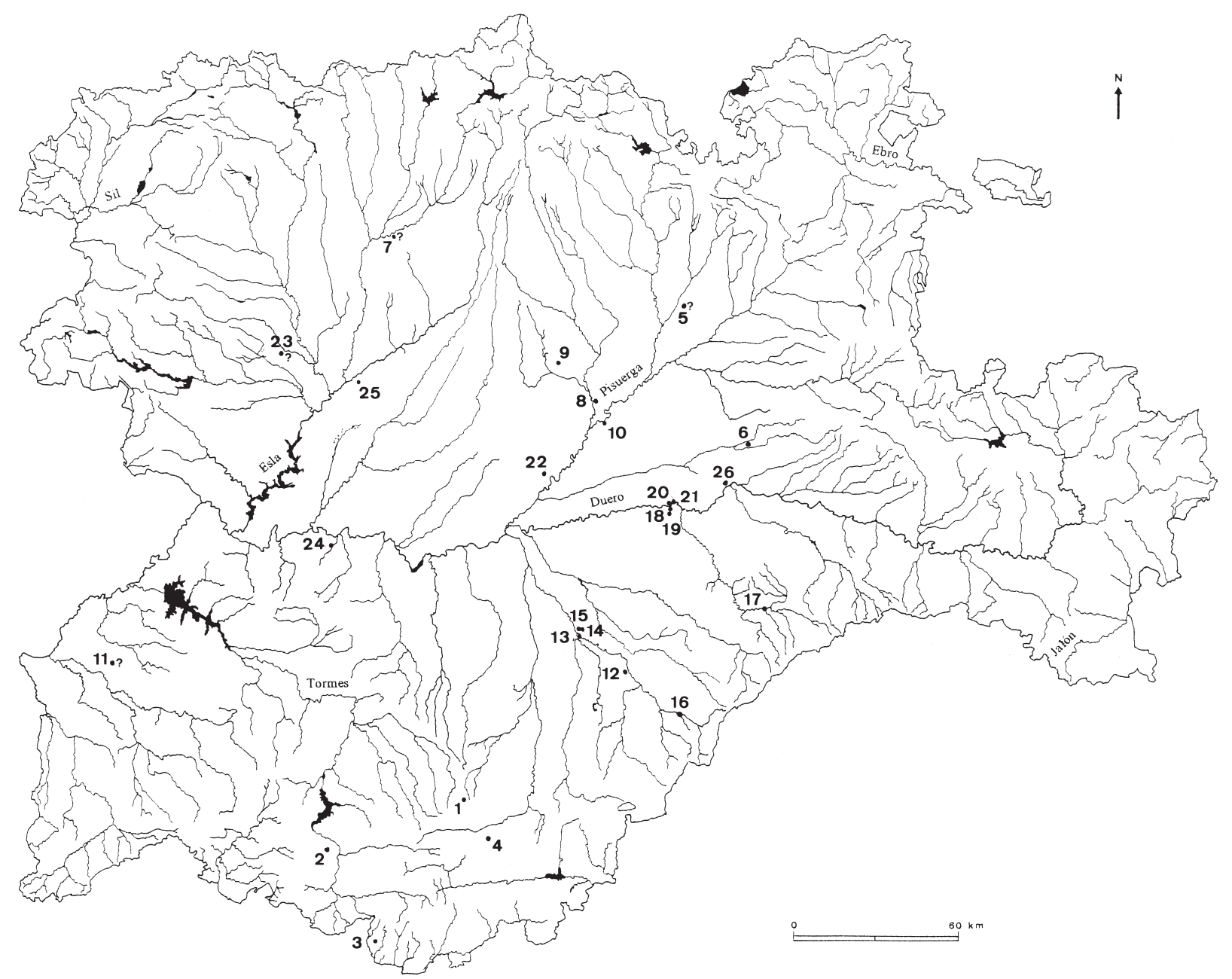

Figura 8.- Cronología de los grupos cerámicos en uso durante la Segunda Edad del Hierro en el Duero Medio, así como de los recipientes argénteos, y sus influencias en la formación de las grises de imitación metálica.

las regiones más permeables a la influencias mediterráneas ya desde los siglos VII-VI a. C. están presentes en la cerámica a torno.

Por ahora los dos únicos yacimientos en los que se documentan platos elaborados en cerámica gris cérea son Coca y el cercano castro de la Cuesta del Mercado, a la sazón barrio o pedanía de Cauca. En ambos casos proceden de contextos domésticos, de los poblados, no de ambientes funerarios, pues aunque la necrópolis de Coca no la conocemos aún, las dos con las que contó el citado castro, sí, y entre los materiales que se pueden observar en su superficie no comparecen (Blanco García, 1994: 66 y 75, fig. 2). Esto nos conduce a pensar, al menos de manera provisional y circunscribiéndonos exclusivamente a la época, espacio geográfico y especialidad vascular que nos ocupa, que se trata de una forma fabricada para usos de mesa que no llega a formar parte de los conjuntos funerarios. Es significativa su falta entre las grises céreas de la necrópolis de Las Ruedas, donde se constatan caliciformes, urnas, oinochoes o vasos de perfil en " $\mathrm{s}$ " pero no platos. (Sanz Mínguez, 1997: 54, H, fig. 20, H, 162-164 y 309-312, fig. 161), aunque el ejemplo quizá no sea muy apropiado por cuanto tampoco en cerámica de cocción oxidante comparecen. En otros momentos y espacios distantes y distintos a los aquí tratados los platos constituyeron una abrumadora mayoría en los enterramientos (p. ej., en la necrópolis de Medellín, donde llegan a alcanzar el 94\% en la Fase II: Lorrio, 1988-89: 285-296 y 308, figs 1-6, 11 y 12), por lo que a pesar de lo observado en el ámbito vacceo no se puede generalizar con que es una forma fabricada exclusivamente para su empleo en la vida diaria. Quizá cuando conozcamos amplios repertorios de vasos funerarios de los siglos II y I a. C. en las tierras del Duero empiecen a hacer acto de presencia, pero por ahora la realidad es esta.

La Variante I 1 es un platito cuyos rasgos morfológicos identificativos son la apreciable inclinación al exterior del borde volado, la sección subrectangular del mismo y la suave curvatura 
de la pared. La pieza que ejemplifica el tipo, inédita, procede de Coca, cuenta con tan sólo 8,8 $\mathrm{cm}$ de diámetro de boca y el borde aparece recorrido por una acanaladura de $4 \mathrm{~mm}$ de anchura, rasgo éste impropio de la cerámica celtibérica que, sin embargo, es muy habitual en buena parte de los platos campanienses. En concreto, nuestro platito gris guarda estrechas relaciones formales con los de la serie 1280 de Morel, fechados en la primera mitad del siglo II a.C. (Morel, 1981: Pl. 11, 1280). Desconocemos qué tipo de base tuvo.

La Variante I 2 cuenta con un borde horizontal de sección lenticular algo aplastado y carena interior que lo separa de la pared suavemente curvada. También caucense la pieza que marca el tipo, tiene $13 \mathrm{~cm}$ de diámetro y ya la dimos a conocer hace unos años (Blanco García, 1993b: 118, fig. 1, 2). Exactamente iguales a éste, pero en pastas anaranjadas, decoración pintada y uno de ellos con grafito, tenemos constatados en Coca otros dos ejemplares exhumados en contextos tardíos, ambos inéditos.

La Variante I 3 tiene por rasgos distintivos un borde corto horizontal de sección subrectangular, paredes muy poco curvadas y fondo con pie anular bajo redondeado. El ejemplar que designa el tipo se recuperó en el Nivel II de la excavación caucense Tierra de las Monedas I, tiene 13 $\mathrm{cm}$ de diámetro, $2,1 \mathrm{~cm}$ de altura y doble perforación localizadas en la inflexión entre el borde y la pared (Blanco García, 1993b: 118, fig. 1, 3).

La Variante I 4 viene definida por tener un borde de tendencia recta pero sensiblemente inclinado hacia el interior, de sección subcuadrangular, unas paredes muy poco curvadas e inflexión acusada entre éstas y el borde. La pieza que ejemplifica el tipo es, como las dos anteriores, conocida ya por proceder de las excavaciones de los años ochenta en Coca (Blanco García, 1993b: 118, fig. 1, 6), su inflexión está marcada en el exterior por una carena y cuenta con un par de perforaciones para su suspensión que han sido practicadas en pleno borde.

Tres rasgos identifican la Variante $I$ 5: un borde de sección lenticular inclinado hacia el interior, paredes bastante curvadas que se precipitan con acusada verticalidad hacia el fondo y, como resultado de esto, cierta profundidad de la cavidad útil. El plato que designa el tipo procede del poblado caucense de La Cuesta del Mercado, posee $15,4 \mathrm{~cm}$ de diámetro de boca, ha recibido un bruñido de mejor calidad por fuera que por dentro y ya lo dimos a conocer en el trabajo que a ese yacimiento dedicamos hace unos años (Blanco García, 1994: 60, fig. 15, 2). También ori- ginario del mismo yacimiento se conoce otro platito de idénticas características técnicas que es perfectamente asimilable a esta variante (Id., 1994: 60, fig. 15, 3), y de la excavación Calle Azafranales n. 5 otro más, pero en este caso fabricado en cerámica común (C/89/Az $5 / \mathrm{XV} / 158)$, que compartía nivel con un nutrido conjunto de cerámicas grises: fragmentos pertenecientes a siete caliciformes nada menos, el bol VI 2 y tres bases.

Platos con perfiles similares al de esta variante fueron muy corrientes entre las producciones grises fechadas, grosso modo, en los siglos IV y III a. C. que al Valle del Duero llegan supuestamente importadas de esa zona oriental de la Submeseta Sur que más en contacto estuvo con el mundo ibérico levantino. En la misma Sepúlveda, por ejemplo, encontramos uno de estos testimonios foráneos que bien pudieron haber influido en las grises céreas (Blanco García, 1998b: 150, fig. 7, 2).

\section{Forma II: fuente (Fig. 1).}

En cerámica gris cérea hasta hace bien poco esta forma estaba representada sólo por un único ejemplar, además incompleto, procedente de Coca (Blanco García, 1993b: 118, fig. 1, 1). Actualmente el repertorio formal es más rico, pues son ya tres las variantes conocidas, aunque todas originarias del citado yacimiento pues, dentro del grupo cerámico considerado, en el resto del Valle del Duero esta forma sigue sin documentarse.

Los rasgos morfológicos comunes a las tres no son otros que los propios de cualquier fuente: destacado predominio de la anchura sobre la altura (ratio 2,20 para el ejemplar completo II 3 pero superior para los otros dos), amplio borde vuelto que se curva suavemente aunque manteniendo una posición horizontal, en voladizo, paredes más o menos curvadas siempre muy abiertas y fondos que, a juzgar por sus homólogos oxidantes, suelen ser predominantemente umbilicados, como el que vemos en la única fuente completa de las tres (II 3), pero presumiblemente también de anillo bajo y redondeado o ligeramente rehundido, nunca totalmente plano. Como rasgo que sin ser común a todas las fuentes sí se constata, sin embargo, en un elevado porcentaje de las mismas -estén fabricadas en cerámica fina oxidante o reductora o bien en barros toscos-, no podemos dejar de señalar el rasgo común de contar con una marcada carena de separación entre borde y cuerpo por la cara exterior del vaso. Los diámetros de las bocas oscilan entre $19 \mathrm{~cm}$ y $25,8 \mathrm{~cm}$, como puede verse 
algo más pequeños que los que encontramos en sus semejantes oxidados, que incluso llegan a alcanzar los 45/50 cm (p. ej., véase Sacristán, 1986: 175, fig. 14, 1 y lám. XXXVI).

$\mathrm{Al}$ igual que los platos hasta ahora conocidos, las fuentes carecen por completo de decoración, son formas lisas en las que, eso sí, podemos encontrar carenas o pares de perforaciones, las primeras como separación entre borde y cuerpo y las segundas para permitir tenerlo suspendido en los momentos en los que no se están usando. Quizá se pudiera entender como decoración sendos círculos impresos que en la Variante II 3 orlan los dos orificios que se han practicado en el borde pero desconocemos si se hicieron con esta intención o con otra. También como hemos observado respecto a los platos, por ahora no conocemos un solo caso en el que las fuentes grises hayan formado parte del ajuar funerario en aquellas necrópolis en las que comparece esta especialidad cerámica (p. ej., en las de Las Ruedas, Carralaceña o Tariego de Cerrato).

La Variante II 1, dada a conocer hace algún tiempo, como más arriba hemos indicado, viene definida por tener un borde vuelto algo curvado, con su extremo no totalmente en horizontal sino apuntando ligeramente hacia abajo, que es prolongación natural del cuerpo tendido y suavemente curvado, es decir, sin carena separadora. La pieza que designa el tipo tiene un diámetro de $24,2 \mathrm{~cm}$ y está excelentemente bruñida tanto por dentro como por fuera. Fuentes y platos a torno con perfiles iguales al analizado están presentes en el Duero Medio desde tiempos muy antiguos, tanto en pastas anaranjadas como grises, estas últimas de los siglos IV y III a. C.

La Variante II 2 cuenta con un borde vuelto curvado cuyo extremo se dispone, ahora sí, en horizontal, contactando con el cuerpo mediante una carena exterior. Cuerpo que, por otra parte, es tendido pero de curvatura tan suave que parece casi recto. La fuente que marca el tipo, aunque también incompleta, es la de mayores dimensiones que hasta ahora conocemos en esta especialidad vascular: $25,8 \mathrm{~cm}$. También de Coca (nivel IX de Tierra de las Monedas II) procede otro ejemplar encuadrable dentro de este tipo, lo que quiere decir que fue un perfil relativamente común, considerando que la mayor parte de los restantes son únicos.

De la Variante II 3 conocemos todas sus características formales gracias a que el vaso que la tipifica se ha conservado completo: borde vuelto curvado en posición horizontal que dobla en ángulo recto para, mediante carena viva, contactar con el cuerpo, a la sazón menos tendido y más curvo que los de las fuentes anteriores, fondo umbilicado y pie redondeado. La pieza en cuestión, de color negro y aspecto acharolado debido al esmero con el que se han pulimentado sus superficies tanto por dentro como por fuera pero no bajo el borde, que se ha dejado rugoso y áspero al tacto, tiene $19 \mathrm{~cm}$ de diámetro de boca y $8,6 \mathrm{~cm}$ de altura. En el punto de inflexión del borde se han abierto un par de perforaciones cada una de las cuales orlada por un círculo impreso sólo marcado en la superficie interna del vaso, que es desde donde se practicaron, algo que en Coca también encontramos en el platito inédito CO/89/TMIII/V/2 y que nos advierte cómo los alfareros celtibéricos disponían de varios tipos de brocas para perforar y lañar los recipientes tal como lo hacían sus homólogos ibéricos y hace años se comprobó, p. ej., en el yacimiento catalán de Darró (Risch et alii, 1986: 297). Referida indistintamente como gran copa, fuente y como frutero en ocasiones, este tipo de recipiente que deriva de prototipos ibéricos de amplia dispersión (Mata y Bonet, 1992: 129, grupo II, tipo 6, subtipo 2, fig. 7, 9), en el Duero es muy corriente encontrarlo fabricado en pastas oxidadas, generalmente pintado, pero con la característica de que se documenta de forma bastante más frecuente en contextos domésticos que funerarios: en los poblados de Roa (Sacristán, 1986: 171-174, fig. 13, 1-5, láms. XXXIVXXXVI) y Coca son decenas los ejemplares que de él se conocen, mientras la necrópolis padillense de Las Ruedas sólo una pieza ha dado (Sanz Mínguez, 1997: 120, L y 281, fig. 118, L y fig. 211, Forma I).

\section{Forma III: cuenco/copa (Fig. 1).}

De nuevo es Coca el yacimiento del que proceden las cinco variantes que englobamos dentro de esta Forma III, dos de las cuales están inéditas. Se caracterizan por ser recipientes de trazas sencillas en los que la anchura máxima se encuentra en la boca, con el borde generalmente redondeado, a veces regruesado, pero también algo apuntados e incluso planos, de tendencia bien exvasada, vertical o invasada, cuerpo hemisférico o en forma de casquete y bases tanto planas como con pie anular y de copa, aunque las más numerosas son las segundas. Como puede verse, es una forma que admite muchas pequeñas variaciones en cada una de sus partes estructurales, de manera exactamente igual a como vemos en su homóloga oxidante, las dos habitualmente referidas por la bibliografía como cuencos, páteras y copas. Otro aspecto en el que tanto las grises como las oxidadas coinciden es 
en el hecho de que, cada una en su grupo, ésta es una de las formas que mejor representación numérica tiene en todos los yacimientos. En pastas anaranjadas esto es comprobable en multitud de lugares y en cerámica gris cérea al menos en Coca, único yacimiento que, por ahora, cuenta con un numeroso y variado repertorio de vasos de este tipo.

Por otra parte, ya en su día señalamos cómo en esta forma y en los platos, más que en otras, se advierten ciertas influencias de la cerámica campaniense. Influencias que creemos detectar no sólo en la aplicación de determinados procedimientos de modelado, sobre todo en los pies anulares, sino también en la misma imitación de las superficies brillantes de aspecto metálico y tacto jabonoso que tienen esas cerámicas, rasgos que adoptaron sobre todo de los vasos de plata pero también en parte procedentes de esta vajilla alóctona. Sobre esta problemática volveremos en las consideraciones finales.

Todos los ejemplares hasta ahora conocidos tienen diámetros de boca que oscilan entre 10,2 $\mathrm{cm}$ y $15,1 \mathrm{~cm}$. Sin embargo, los umbrales métricos en la altura (entre $5,3 \mathrm{~cm}$ y $10,4 \mathrm{~cm}$ ) están más distanciados como consecuencia, fundamentalmente, de las diferencias existentes en los tipos de base.

Aunque no faltan los lisos, en barros oxidados estos recipientes suelen estar ornados con pintura, pero en los grises de superficies bruñidas y tacto céreo la decoración está por completo ausente, al menos por ahora. De nuevo estamos, por tanto, ante una forma lisa.

El vaso que ejemplifica la Variante III 1, incompleto, tiene como elemento definitorio el contar con un borde plano de tendencia invasada que por el exterior ha sido suavemente moldurado, lo cual es poco frecuente en los recipientes de este tipo (Blanco García, 1993b: 118, fig. 1, 12), pero que nos remite a determinado tipo de cuencos en pastas anaranjadas procedentes de Herramélluri que fueron englobados por A. Castiella dentro de su forma 1 (Castiella, 1977: 310, fig. 255, 1-4).

La Variante III 2 se distingue formalmente por el predominio de la anchura sobre la altura (índice 2,69), tener un borde redondeado ligeramente invasado, cuerpo en forma de casquete esférico y base totalmente plana. El cuenco concreto que nos sirve para señalar el tipo, inédito hasta ahora, tiene un diámetro de $14,3 \mathrm{~cm}$ y una altura de 5,3 $\mathrm{cm}$. Este tipo de perfil es muy frecuente en pastas oxidadas pero lo encontramos mayoritariamente con pie anular bajo o simplemente con el fondo un poco rehundido, no ápodo. Los de base plana casi siempre, al menos en Coca, comparecen en contextos tardíos, de los siglos II y I a. C.

La Variante III 3 es un cuenco o pátera de proporciones muy equilibradas, ligeramente más ancho que alto (ratio 2,02), borde redondeado vertical un poco engrosado, cuerpo casi hemisférico y fondo suavemente elevado sobre un pie anular bajo. El recipiente que ejemplifica esta variante tiene $13,6 \mathrm{~cm}$ de diámetro máximo, 6,7 $\mathrm{cm}$ de altura y procede del mismo sondeo y nivel que el platito I 3, recuperados ambos con otros diez fragmentos también grises céreos de variada tipología. Este vaso y otro de idéntica tipología más algunos fragmentos que a ella pudieran también pertenecer ya los dimos a conocer hace un tiempo (Blanco García, 1993b: 118, fig. 1, 7-9, 13 y 16), por lo que se puede decir que fue una forma común en cerámica gris cérea. En cerámica oxidante este es el tipo de cuenco o pátera más abundante en Coca y otros muchos yacimientos del Duero Medio, comúnmente decorado con bandas de pintura ocre, anaranjada o roja tanto por dentro como por fuera y por lo general de cronología tardía. Esta es otra de las formas en las que parecen proyectarse influencias de algunas evolucionadas páteras campanienses del siglo II e inicios del I a. C. incluidas en las series 2780 y 2980 de Morel (1981: Pls. 72-74, 84 y 85).

La Variante III 4 es un cuenco que por su elevado pie comúnmente recibe el nombre de copa. Cuenta con un borde redondeado vertical, cuerpo hemisférico que apoya sobre un pie elevado, de copa, con una serie de molduras entre ambos. La pieza que designa el tipo, presentada fotográficamente hace poco (Pérez González y Blanco García, 2000: 44 y fot. de p. 39), tiene 13,8 cm de diámetro de boca y $10,4 \mathrm{~cm}$ de altura (índice 1,32). En cerámica oxidante el tipo es muy antiguo, pues prácticamente idéntico ya lo encontramos formado desde los mismos inicios de la llegada del torno al Valle del Duero. Fuera de aquí, en barro gris lo encontramos fechado entre los siglos IV y II a. C. en la necrópolis alcarreña de Luzaga (Díaz Díaz, 1976: 468, 477 y 488, fig. 19, 7).

Mientras las variantes anteriores tienen el borde invasado o vertical, lo que distingue a la Variante III 5, a pesar de estar muy incompleta, es la tendencia exvasada del mismo. El fragmento que designa el tipo procede del nivel XXII de la excavación Convento II y otro de las mismas características se recupero en el nivel XII de Tierra de las Monedas II (Blanco García, 1993b: fig. 1,15 y 14, resp.).

\section{Forma IV: mortero (Fig. 1).}

Ninguna de las variantes pertenecientes a esta 
Forma IV se ha conservado completa ya que les faltan las bases, pero todas son bien conocidas en barros oxidantes. Esto último nos permite poder afirmar que apoyaban en un pie bajo de tipo copa, lo que unido al grosor que suelen tener sus paredes justifica que sean referidas en la bibliografía como copas bajas de tipo mortero, denominación que lleva implícita una doble funcionalidad y que crea un problema sobre el que ya algunos autores han incidido al considerar que, por una parte, los tipos de borde que tienen, generalmente muy gruesos, moldurados en el exterior y abombados por el interior, resultan del todo inapropiados para beber y ser utilizados, por tanto, como copas; y por otra, que el tipo de pie que poseen la mayoría de ellos no soportaría el golpeo de la mano del mortero, además de que en el interior de estos vasos no suele haber huellas de dicho golpeo (salvo en un ejemplar procedente del Ayuntamiento de Roa: Sacristán, 1986: 174, lám. LXXXII, 2), lo que restaría peso a su identificación como triturador de sólidos. Por nuestra parte, no creemos que haya que relacionar con una única función todas las variables formales que se conocen. Como hemos hecho en otras ocasiones, por comodidad y dejando al margen esta cuestión, nosotros vamos a referirnos a esta forma simplemente como mortero. Lo que por el momento sí parece una tendencia es que estamos ante un recipiente de uso doméstico más que funerario o cultual.

En cerámica gris cérea, los diámetros de boca de los ejemplares hasta ahora conocidos oscilan entre $6,6 \mathrm{~cm}$ y $10,8 \mathrm{~cm}$, unas medidas en general algo menores que las que podemos obtener de sus semejantes anaranjados pues si tomamos como muestra, por ejemplo, el amplio repertorio numantino recogido por F. Wattenberg (1963: 178-181, tabs. XXII y XXIII) el más pequeño tiene $9 \mathrm{~cm}$ y el mayor alcanza los $15,6 \mathrm{~cm}$. Sus coloraciones van desde el gris ceniciento al negro, están siempre mejor bruñidos por fuera que por dentro y presentan abundantes signos externos de haber sido usados durante mucho tiempo.

Por ahora no conocemos un solo vaso adscribible a esta forma que tenga decoración. Nuevamente estamos, por tanto, ante una forma lisa. Sin embargo, en ella sí suelen ser corrientes las molduras en la zona exterior del borde, las cuales contribuyen a realzarlo por el contraste de claroscuro que se produce y que sin duda provoca cierto efecto ornamental, pero esto no autoriza a clasificarla como decorada.

Los vasos que ejemplifican las cuatro variantes individualizadas proceden de Coca (Blanco García, 1993: 118-120, fig. 1, 10 y 17-19 resp.), recuperados, por tanto, en contextos habitacionales.

De la Variante IV 1 sólo tenemos el borde y parte superior del cuerpo pero es suficiente para advertir que estamos ante una peculiar forma bien conocida en cerámica oxidante que se caracteriza por tener paredes gruesas, un borde bastante almendrado hacia el interior, de sección más o menos ovalada, y un cuerpo que no llega a ser hemisférico. Se corresponde con la forma VII 2 de la necrópolis de Las Ruedas (Sanz Mínguez, 1997: 287-288, fig. 211, VII 2) y es uno de los perfiles mejor documentados en Numancia, al que Wattenberg relacionaba directamente con la campaniense y dató en los mismos momentos en los que hoy fechamos las grises céreas: finales de la segunda centuria antes de Cristo y comienzos de la siguiente (Wattenberg Sanpere, 1963: 43, varios ejemplares en 178-181, tabs. XXII y XXIII).

La pieza gris que ejemplifica el tipo tiene 8,8 $\mathrm{cm}$ de diámetro de boca, es de superficies muy bruñidas de color claro y carece por completo de molduras y de decoración (Blanco García, 1993b: 118-120, fig. 1, 11). En Coca el tipo también está presente en cerámica anaranjada, formando parte de contextos siempre avanzados, de los siglos II y I a. C.

En la Variante IV 2 encontramos un perfil por ahora único en cerámica gris que, sin embargo, resulta conocido en pastas rojas pintadas, al menos en Coca (CO/89/TMII/VII/5). Se caracteriza por ser de paredes más gruesas en la mitad superior que en la inferior, poseer un borde de perfil lenticular abombado hacia dentro que también se prolonga suavemente hacia fuera en virtud de la ancha acanaladura que hace los efectos de cuello corto y un cuerpo que tiene más de troncocónico que de hemisférico (Blanco García, 1993b: 118-120, fig. 1, 18). El vaso tipificativo es de dimensiones muy pequeñas: tiene un diámetro de boca de $6,6 \mathrm{~cm}$ y una altura presumiblemente no mayor de los 8 ó $9 \mathrm{~cm}$.

El vaso que ejemplifica la Variante IV 3 fue recuperado en el nivel XVIIa del sondeo practicado en la Calle Azafranales n. 5 (Blanco García, 1993b: 118-120, fig. 1, 17), junto a fragmentos pertenecientes a otros nueve vasos más también grises de superficies céreas y un caliciforme anaranjado pintado. Es de paredes bastante espesas, con borde abombado al interior y algo extendido al exterior insinuando una pequeña cornisa, hombro marcado por un baquetón flanqueado por sendas acanaladuras y cuerpo hemisférico que se va haciendo más grueso conforme se aproxima a la base. Tiene 10,8 cm de diámetro de boca. 
De la Variante IV 4 es francamente poco lo que se puede decir: tiene un borde de perfil subrectangular algo inclinado hacia dentro, sin apenas abombamiento al interior pero prolongado al exterior de manera que se crea una pequeña cornisa, y cuerpo aparentemente hemisférico (Blanco García, 1993b: 118-120, fig. 1, 19). Más que en el mundo vacceo o celtibérico, es en el ibérico levantino en el que, en pastas rojas, encontramos paralelos para este tipo (Mata y Bonet, 1992: 135, fig. 17, 1).

\section{Forma V: cubilete (Fig. 1).}

Esta es una forma por ahora única en esta especialidad cerámica a la que, en previsión de futuras variantes que se pudieran ir documentando, hemos dado el código identificativo V 1. Las características morfológicas de este perfil cuenquiforme son: boca tendente al cerramiento con el borde muy vuelto, en gancho, y cuerpo globular que alcanza los dos tercios de la esfera. Desconocemos qué tipo de base pudo haber tenido, si era plana, umbilicada o con pie. Lo que el fragmento conservado sí permite decir es que se trata de una forma lisa. Procede de Coca, nivel XVI de la excavación Avda. de la Constitución n. 8 (Blanco García, 1993a: 164, fig. 7, 10), y formaba contexto con quince fragmentos de las mismas características técnicas que pertenecieron al menos a ocho vasos y con cuatro caliciformes de pastas anaranjadas decorados con pintura e idénticos a los grises que más adelante veremos (vid. Fig. 7). Resulta bastante rara en barros oxidantes, existiendo una posibilidad quizá algo lejana de que sus precedentes fueran determinadas formas por ahora sólo conocidas en el madrileño Cerro Redondo, también grises bruñidas por cierto, aunque en versión grande (Blasco y Alonso, 1985: 98 tipo VI, fig. 35, 10 y 11),

\section{Forma VI: bol (Fig. 1).}

Los tres vasos que individualizan otras tantas variantes englobables dentro de esta Forma VI, así como varios fragmentos más de bordes adscribibles a la misma, ya en su día los dimos a conocer bajo la denominación de boles (Blanco García, 1993b: 120, fig. 2, 20-24; Id., 1994: 60, fig. 15,6$)$. A pesar de que ninguno se ha conservado completo, morfológicamente son recipientes en los que, por lo general, predomina la anchura sobre la altura, tienen perfil globular como consecuencia de que suelen sobrepasar la mitad de la esfera, bocas tendentes al cerramiento $\mathrm{y}$ bordes a veces algo engrosados y moldurados con labios redondeados. Cotejando esta forma con sus iguales oxidantes podemos decir que las bases pudieron ser umbilicadas o de anillo bajo, más infrecuentemente con pie de copa. Los diámetros de boca de los ejemplares conocidos hasta ahora van desde los 11,4 cm del más pequeño hasta los $17 \mathrm{~cm}$ del mayor.

Desde el punto de vista ornamental, en esta forma encontramos tanto piezas lisas como decoradas. Los baquetones y las acanaladuras horizontales suelen estar casi siempre presentes en ellas pero también tenemos constatadas, aunque de manera más escasa, los puntos impresos, las estampillas y las líneas bruñidas a espátula formando diseños geométricos.

La Variante VI 1 procede del poblado de La Cuesta del Mercado, tiene 12,3 cm de diámetro de boca, ha sido excelentemente bruñido por fuera y en el labio interno pero simplemente alisado por dentro (Blanco García, 1994: 60, fig. 15, 6). Es una forma muy corriente entre las cerámicas de cocción oxidante, generalmente pintada, que estuvo en uso en el Valle del Duero prácticamente desde los mismos inicios de la llegada del torno, por lo que no es extraño que también en esta especialidad gris esté presente. La decoración se dispone a ambos lados del único baquetón que tiene: sobre él, una hilera de puntos impresos que contribuye a resaltar la horizontalidad de la pieza, y debajo, anillos también impresos.

La Variante VI 2 es una sencilla forma de bol con el borde redondeado y algo regruesado, de tendencia invasada, que está separado del cuerpo hemisférico por medio de dos baquetones muy próximos entre si. La pieza que ejemplifica el tipo procede del nivel XV del sondeo excavado en la calle Azafranales n. 5, tiene $17 \mathrm{~cm}$ de diámetro, e idéntica pero de dimensiones un poco menores e inédita conocemos otra exhumada en un punto central de Coca. En ambos casos se trata de piezas lisas.

La Variante VI 3 es la más cuenquiforme de las tres por la proporción que guardan la anchura de la boca y el diámetro máximo con la altura que probablemente tuvo. Su perfil comprende los dos tercios de la esfera, tiene $12,5 \mathrm{~cm}$ de diámetro de boca, el borde y la zona media han sido ensalzados por medio de baquetones dobles y conserva un arranque de asa en esta zona de máxima anchura pero del que no hay restos de su correspondiente en la parte del borde, por lo que pudo ser horizontal, como los que vemos en algunos caliciformes (p. ej., Sanz Mínguez, 1997: 164 n.320, fig. 161, 320). Desconocemos qué tipo de base tuvo, tal vez umbilicada o de copa. Es uno de los vasos del grupo que más aspecto metálico tiene debido al color negro intenso de 
su superficie exterior y al brillo acharolado que se ha conseguido mediante un cuidadoso bruñido. Entre los pares de baquetones, un friso de grupos de tenues líneas paralelas realizadas a espátula y dispuestas en dirección alternante, en zig-zag, contribuyen a dar a la pieza un mayor atractivo (Blanco García, 1993b: 120, fig. 2, 21). De esta podemos decir, por tanto, que es una variante decorada.

\section{Forma VII: esferoide (Fig. 1).}

Por ahora es una sola pieza la que da carta de naturaleza a esta sencilla y ancestral forma caracterizada por tener una boca bastante cerrada, borde muy corto, redondeado y vertical, y cuerpo globular u ovoide, pues desconocemos la mitad inferior y con ello el tipo de base que pudo haber tenido, aunque lo más probable es que fuera umbilicada. Una vez más, su procedencia es caucense (Blanco García, 1993b: 120, fig. 2, 32 ), tiene $8 \mathrm{~cm}$ de diámetro de boca, $15,2 \mathrm{~cm}$ de anchura máxima, color gris oscuro, bruñido de excelente calidad sólo en su superficie externa, carece por completo de decoración y en cerámica de mesa oxidante a torno es poco corriente. Por forma y tamaño, pero en estos barros oxidados, sería asimilable al tipo XII.1 de la necrópolis de Carratiermes, fechable entre los siglos $\mathrm{V}$ y II a. C. (Argente, Díaz y Bescós, 2001: 184, fig. 63). En el castro de Tariego de Cerrato existe un vaso de perfil y proporciones muy similar a éste que se ha conservado completo y por la decoración pintada que porta parece ser también bastante tardío (Castro García y Blanco Ordás, 1975: lám. XXXVII, 8). De tamaño menor y paredes sensiblemente más espesas, entre los materiales hallados en posición secundaria de la necrópolis de Las Ruedas también se encuentra un cuenco de pasta anaranjada casi completo que guarda un estrecho paralelismo formal con nuestro vaso gris (Sanz Mínguez, 1997: 156 n. 221, fig. 154, 221).

\section{Forma VIII: vaso de perfil en "S" (Fig. 2).}

Las variantes consignadas son todas ellas de tamaño pequeño, con bocas que oscilan entre 8 y $12,8 \mathrm{~cm}$ y alturas aproximadas entre 6 y $12 \mathrm{~cm}$ (9,8 cm la VIII 2, única completa). Por otra parte, ninguna de ellas presenta decoración, por lo que se puede decir que, por ahora, esta es una forma lisa, la séptima de las ya analizadas.

De esta forma hemos distinguido cuatro variantes basándonos en los tipos de borde, en la mayor o menor glubulosidad de los cuerpos y en la relación entre la anchura de boca y la altura que razonablemente se puede presumir para las incompletas.

De la pieza que ejemplifica la Variante VIII 1, inédita, no conocemos ni su borde ni su base pero tomando en consideración el ancho cuerpo bulboso que no encontramos en ninguna de las otras, que debió de tener una boca bastante cerrada y que presumiblemente es más ancho que alto, se ha considerado como tipo peculiar no asimilable a ninguna de las otras tres variantes de vasos de perfil en "S". Tiene una anchura máxima de $10 \mathrm{~cm}$, el color de la pasta es gris pero la superficie exterior es de un negro intenso muy pulido, acharolado, estando la interior simplemente alisada. De procedencia caucense, con él aparecieron otros muchos fragmentos más pertenecientes al menos a 11 vasos, entre ellos el plato I 1, cuatro fragmentos de caliciformes (uno decorado con la composición 19) y una base con grafito en el exterior (Fig. 3, 6.1).

La Variante VIII 2 se caracteriza por ser más ancha de boca que alta, tener un borde suavemente exvasado con el labio algo apuntado, un cuerpo abombado y una base plana. El vaso que marca el tipo, único de los en "S" del que conocemos prácticamente todo su perfil, tiene 12,8 cm de diámetro de boca, $9,8 \mathrm{~cm}$ de altura, es de superficies negras y se halló en la necrópolis de Las Ruedas (Padilla de Duero, Valladolid), aunque en posición secundaria (Sanz Mínguez, 1997: 164 n. 318, 310, fig. 161, 318).

El vaso que designa la Variante VIII 3 tiene como rasgos más destacados que le diferencian de las anteriores un predominio de la altura (en torno a los $10 / 11 \mathrm{~cm})$ sobre la anchura de boca $(8$ $\mathrm{cm})$, un borde también suavemente exvasado como la VIII 2 pero con el labio redondeado y más corto, lo que hace que su cuello, igualmente corto, y el hombro se sitúen en una posición más elevada, pareciendo así el cuerpo más globular. Procede de Coca, en concreto del nivel V de la excavación Tierra de las Monedas II (Blanco García, 1993b: 120, fig. 2, 26), donde compartía estrato con fragmentos pertenecientes a otros tres vasos grises y otros muchos oxidantes polícromos en los que las pinturas blancas están bien representadas, lo que podría estar significando que esta es otra de las formas cuya vida útil sobrepasó los comedios del siglo I a. C. o que hemos de llevar la incorporación de la pintura blanca a fechas más antiguas de las que hoy manejamos. Sobre este interesante aspecto luego volveremos.

La Variante VIII 4, señalada por otro vaso de Coca hasta ahora inédito del que sólo nos ha llegado el tercio superior, comparte formalmente 
con la anterior únicamente el ser, con toda probabilidad, más alta que ancha de boca $(8,2 \mathrm{~cm})$, pues por lo demás son distintas. Su borde es muy grueso, corto y de perfil insinuadamente cefálico, el cuello ha quedado reducido a la mínima expresión, el cuerpo es destacadamente globular y el hombro gana en horizontalidad.

\section{Forma IX: oinochoe (Fig. 2).}

Una sola pieza da carta de naturaleza a esta nueva forma que en el repertorio hasta ahora conocido no constaba. Se trata de un oinochoe o jarra de pico que fue recuperada entre los materiales descontextualizados de la necrópolis padillense de Las Ruedas (Sanz Mínguez, 1997: 164 n. 319, 310, fig. 161, 319). Morfológicamente se define por tener una boca con pico vertedor (aunque en la ilustración no aparezca representado), amplio borde vuelto con el labio redondeado que incide en ángulo recto respecto al hombro y del cual está separado por medio de un fino baquetón liso y cuerpo aparentemente bitroncocónico cuya inflexión de la pared aparece marcada por una incisión ancha o acanaladura en un punto probablemente medio del mismo. En la publicación que lo dio a conocer no se dice nada de que conservara indicios del asa. De color gris, la superficie exterior muestra el lustre característico que le da el tratamiento bruñido de que ha sido objeto. El diámetro máximo de la pieza es de $13,7 \mathrm{~cm}$ y al menos uno de los dos que se suelen obtener en las bocas sinuosas de estas jarras es de $8,8 \mathrm{~cm}$ (medido a partir de la ilustración).

Con carácter provisional, pues sólo es esta jarra la que representa el tipo, hay que decir que estamos ante una forma lisa. En pastas oxidadas, las jarras, tanto de cuerpo bitroncocónico como bulboso, suelen estar decoradas con pintura en la zona del hombro, por lo que quizá en un futuro conozcamos ejemplares decorados en pastas grises.

\section{Forma X: caliciforme (Fig.2).}

Esta es la forma más característica, abundante y difundida geográficamente de todas cuantas conforman el repertorio tipológico de la especialidad cerámica analizada. Además, presente tanto en contextos domésticos como funerarios y estrechamente relacionada con recipientes argénteos contemporáneos desde el punto de vista morfológico y ornamental. Todo ello explica que sea de la que más se ha escrito hasta ahora. Sobre la misma en una ocasión anterior ya expusimos algunas ideas sobre la posición que ocupan en el contexto de las del resto de la
Península Ibérica que no parece procedente ahora repetir (Blanco García, 1993b: 123-126). En el presente trabajo hemos distinguido dos variantes principales que se corresponden, respectivamente, con las formas XIV y XIIIB de la tipología de E. Wattenberg (1978: 30-32, 45). Ambas se caracterizan por el equilibrio que guardan el diámetro de boca y la altura -lo que hace que la ratio anchura/altura sea muy baja (en torno a 1,25)-, tener bordes exvasados muy desarrollados, en forma de campana, ser su anchura máxima siempre la del diámetro de la boca, cuerpos hemisféricos o bulbosos en algunas ocasiones y bases generalmente umbilicadas, aunque no son extrañas otras como las casi planas. En algún caso puede llevar asitas horizontales situadas a media altura, junto a la línea de carena (Sanz Mínguez, 1997: 164 n. 320, fig. 161, 320 ), pero lo que no se advierte en ninguna de las piezas conocidas hasta ahora es que de la zona del borde o de la carena arrancara algún asa vertical que nos indujera a pensar en que algunas fueran tazas como la supuestamente prototípica del nivel III de Las Quintanas (Gómez Pérez y Sanz Mínguez, 1993: 360, fig. 7, 3), las constatadas en pastas rojas (p. ej., Sanz Mínguez, 1997: 115, fig. 112, E; Wattenberg Sanpere, 1963: 170, tab. XVI, 444 y 445; Arenas Esteban, 198788: 99, fig. 5, 15 y 16; Id., 1999: fig. 129) o bien simpula como el broncíneo del poblado navarro de La Custodia dado a conocer por Labeaga y fechado hacia mediados del siglo I a. C. (Labeaga Mendiola, 1985: 575-576, fig. 5 y foto 2; Id., 1999-2000: 132-133, fig. 448; Martín Valls, 1990: 146 y 155-156, fig. 1, Tipo IV).

En general, son vasos de color gris uniforme minoritariamente negros-, que han sido muy bien bruñidos, y en algunos casos pulidos, siempre por el exterior y el borde interno hasta la altura del hombro. A pesar de ser de pastas duras, sus delgadas paredes hacen que sea el vaso más frágil de cuantos conforman el grupo de grises céreos, razón por la que en casi todos los yacimientos suele aparecer muy fragmentado.

Esta es una forma eminentemente decorada, hasta el punto de que de un total de cuarenta y cuatro ejemplares hasta ahora contabilizados en la Cuenca del Duero, tanto completos como fragmentarios (en este segundo caso de indudable adscripción tipológica y suficientemente grandes como para apreciar sus características), sólo cinco son lisos, aunque, eso sí, tienen baquetones y acanaladuras en sus hombros. Como consecuencia de la simetría que caracteriza a las decoraciones de los objetos artesanales celtibéricos en general, casi siempre son reconstruibles los frisos con los que se han ornado. 
La Variante $X 1$ acoge a todos los vasos caliciformes conocidos hasta ahora excepto al pequeño vasito que hemos individualizado como variante X 2 por contar con rasgos propios que le distinguen morfológicamente de aquélla. Entre piezas completas y fragmentos de indudable adscripción a esta variante, se conocen en la actualidad cuarenta y dos ejemplares. Los rasgos que caracterizan a este grupo mayoritario son el tener un diámetro de boca de longitud semejante al de su altura, boca acampanada como consecuencia de contar con un prolongado borde exvasado que generalmente supone un tercio de la altura del vaso, labio redondeado y a veces algo engrosado, cuerpo hemisférico que en algún caso puede llegar a ser bulboide en cuya parte superior la pared se cierra de manera suave para dar lugar a un hombro que por lo general es soporte de baquetones, acanaladuras y decoración incisa o impresa, y base en la mayor parte de las ocasiones umbilicada. Los diámetros de boca van desde los $12,2 \mathrm{~cm}$ del ejemplar más pequeño hasta ahora conocido (el 316 de Las Ruedas) a los $21,2 \mathrm{~cm}$ del mayor (Tariego), con una media establecida en $14,9 \mathrm{~cm}$ a partir de las veintitrés piezas que más completas se conservan. Sólo nueve de ellas permiten conocer las alturas, que oscilan entre 10,1 y $17,6 \mathrm{~cm}$, con $12,7 \mathrm{~cm}$ de media, quedando establecidos los índices entre 1,14 y 1,40, con 1,25 de media.

Si bien no faltan los lisos (Blanco García, 1993b: fig. 4, 45, 48 y 49 y fig. 5, 57, p. ej.), estos vasos capitalizan la mayor parte del repertorio de composiciones decorativas documentadas en el grupo de cerámicas grises, desde los diseños más elementales conseguidos a base de repetir un único elemento decorativo -sean simples incisiones, rehundidos, acanaladuras, sencillas impresiones, etc. (Fig. 3)-, a los muy elaborados (Fig. 4, 2-7, 11, 12, 14-16, 18-20, 22; Fig. 5, 23-25, 28-35, 38 y 39$)$.

Desde el punto de vista geográfico, esta variante de caliciforme es la más difundida por el Valle del Duero. Se constata con seguridad en los lugares abulenses de La Mesa de Miranda (Cabré, Cabré y Molinero, 1950: lám. XIX, 23, 27 ¿y 10?), Las Paredejas-El Berrueco (Piñel, 1976: 363-365, fig. 11, 2 y 3) y Ulaca (Posac Mon, 1952: 7 ¿y 4?); en el leonés Pico del Horno en Valle de Mansilla (Celis Sánchez, 1996: 58, fig. 5, 11); en la necrópolis palentina de Tariego de Cerrato (Castro García y Blanco Ordás, 1975: 132-133, 15, lám. XXXIX, 15; Wattenberg García, 1978: 32, 45 y 58, forma XIV.); en los yacimientos segovianos del Cerro de la Virgen de Tormejón en Armuña (fragts. inéditos), Cauca (Blanco García, 1993b: 123-126, fig. 3, 39-43, figs. 4 y 5; Pérez González y Blanco García, 2000: 38, 39 y 44), Segovia capital (Molinero, 1971: 70, 2610, lám. CXV, fig. 1, 5-1), Sepúlveda (Blanco García, 1998b: 152-155, fig. 11, 10 y 11) y la finca de Los Mercados de Duratón (fragts. inéditos); en los yacimientos vallisoletanos de la necrópolis de Las Ruedas (Sanz Mínguez, 1997: 54, fig. 20, H, 162-164, fig. 161, 300, 301, 302, etc., 309-312), la necrópolis de Carralaceña (Sanz Mínguez, Gómez Pérez y Arranz Mínguez, 1993: 132, fig. 2, M, N y O, 134, fig. 5, G, y 142-144; Sanz Mínguez, 1997: 42-43 y 309, fig. 11, M, N y O, y XXVI), Gorrita (Wattenberg Sanpere, 1959: 210-211, tab. XIV, 14); y en el poblado zamorano de La Dehesa de Morales (Celis Sánchez, 1990: 473-474, fig. 9, 7-10 y 12), pudiendo estar presente también, aunque no es seguro, en el castro de Las Labradas, en Arrabalde (Balado Pachón, 1999: 22-24, fig. 3, 6). Como tampoco es seguro, pues la bibliografía al respecto no lo explicita claramente, en Palencia capital (Sanz Mínguez, Gómez Pérez y Arranz Mínguez, 1993: 142; Sanz Mínguez, 1997: 311) y quizá en algún otro yacimiento más como Picón de la Mora (Martín Valls, 1971: 133-134, fig. 3, 7).

En las tierras que orlan el Duero, caliciformes grises de imitación metálica, lisos o decorados con composiciones idénticas o semejantes a los de allí, los encontramos, por ejemplo, en el poblado abulense de El Raso de Candeleda (Fernández Gómez y López Fernández, 1990: fig. $6,44-85$ y fig. 8, 6.1), en la necrópolis madrileña del Cerro de la Gavia, aunque en este caso fechados de manera poco acertada en los siglos IV y III a. C. por creerlos adscribibles a las estampadas de esos siglos (Blasco y Barrio, 1991: 287 y 301, fig. 5, 3 y 4), en la de Luzaga con fechas estimativas que van desde el siglo IV al II a. C. (Díaz Díaz, 1976: 467, 477 y 488, fig. 19, 5) o en la sepultura 9 de La Yunta desempeñando la función de urna cineraria (García Huerta, 1989: 387, fig. 93). Resulta cuando menos sintomático del proceso evolutivo que pudieron experimentar los caliciformes el que en el referido yacimiento madrileño se haya documentado un fragmento perteneciente a esta forma y decorado igual que los torneados pero hecho a mano (Blasco y Barrio, 1991: 286 y 301, fig. 2, 2; Blasco y Lucas, 1999: fig. 3, C, 2), aunque de nuevo llevado a cronologías que creemos altas en exceso.

El caliciforme es un tipo cerámico que con idénticas características técnicas, formales y decorativas encontramos también en barros oxidados (Sanz Mínguez, 1997: 164 n. 310, 310 y fig. 161, 310; varias piezas incompletas e inéditas en Coca); que también se produjo incluso sin el bruñido que distingue las superficies externas de 
estas especies (Sanz Mínguez, 1997: 164 n. 306, 310 y fig. 161, 306); que, al menos en Coca, vemos compartiendo contexto con sus iguales anaranjados tanto lisos como decorados con pintura (Fig. 7); y, en cuarto lugar, que, con algunas diferencias, también se fabricó a mano, como vemos en el nivel III del poblado de Las Quintanas (Gómez Pérez y Sanz Mínguez, 1993: 360, fig. 11, 3) o en el referido Cerro de la Gavia (Blasco y Barrio, 1991: 286 y 301, fig. 2, 2; Blasco y Lucas, 1999: fig. 3, C, 2), no sabemos si exclusivamente antes de que empezaran a fabricarse los torneados, como parece evidente por lo que al ejemplar ansado vallisoletano se refiere, o también simultáneamente a ellos. Todo esto lo que nos está indicando es que la "popularidad" alcanzada por esta forma fue tal en las décadas a caballo entre los siglos II y I a. C. que, además de ser la más abundante y extendida geográficamente en cerámica gris cérea se estuvo fabricando en otras especialidades alfareras. Tan cierto es que en los caliciformes grises céreos se dan cita múltiples elementos formales y ornamentales tomados de recipientes anteriores (cerámicos a mano y a torno así como metálicos) ${ }^{4}$ como, a nuestro entender, que ellos a su vez provocaron la generalización de una moda que se extendió cada vez a más formas y penetró en otros grupos cerámicos, pero marcar con cierta precisión los tiempos del proceso acaecido resulta por ahora imposible.

La Variante $X 2$ viene representada por un único vaso de dimensiones pequeñas que procede de La Plaza Mayor de Coca (Blanco García, 1993b: 126, fig. 4, 52). Comparte con la anterior una serie de rasgos que no vamos a repetir, teniendo como propios el que sus proporciones son menos equilibradas que las de aquélla, su borde constituye no ya un tercio de su altura sino la mitad, el cuerpo se ha reducido considerablemente, está menos desarrollado al no llegar a la mitad de la esfera, y la base es casi plana, sólo está ligeramente rehundida en el centro. Tiene $8,8 \mathrm{~cm}$ de diámetro de boca, $7,1 \mathrm{~cm}$ de altura (índice 1,23), superficie externa e interior del borde finamente bruñidos, de color negro. El contacto entre borde y cuerpo se resuelve mediante un baquetón sobre el que se ha dispuesto un collar de óvalos impresos en posición inclinada, alternando debajo palmetas y anillos

4. Al tiempo que en estos vasos caliciformes influyen los argénteos, también lo hacen producciones cerámicas igualmente grises y acabados exteriores esmerados que estuvieron en uso durante los siglos III y II a. C. en prácticamente todo el centro peninsular. Pensemos, por ejemplo, en los caliciformes grises existentes en igualmente impresos (Fig. 5, 36) Esto quiere decir que es una forma decorada, aunque entre los supuestos modelos de los que deriva hay ejemplares lisos. Guarda estrechas relaciones morfológicas con la tulipa negra mate de Simancas representativa de la forma XIIIB de E. Wattenberg (1978: 30 y 45, XIIIB), a la que se le estima una fecha del primer cuarto del siglo I a. C., con un caliciforme gris de la cueva turolense del Coscojar fechado entre los siglos III y I a. C. (Perales García, 1989: 36-37 y 118-119, fig. 41, 3), y en pasta roja, con algún vaso de la necrópolis de La Yunta datado a finales del siglo III y primera mitad del II a. C. (García Huerta y Antona del Val, 1992: 26 y 169, fig. 13, 9). Todas estas piezas centropeninsulares nos remiten, en definitiva, a los vasos ibéricos englobados por Mata y Bonet en el subtipo 4.3 del grupo III (1992: 133, fig. 12, 9, 11 y 12), presentes tanto en contextos antiguos como plenos del mundo ibérico, y muy habituales en cuevas santuario levantinas como, por ejemplo, la de Marinel (Martínez Perona, 1992: 265, fig. 2, 1, lám. I, 3) o las del Puntal del Horno Ciego (Gil-Mascarell, 1977: 709, figs. 1, 1 y 2, 1; Martí Bonafé, 1990: 151-153, fig. 5, 7042, fig. 6 , 7047, fig. 12, 7109, etc.).

Al margen de la variabilidad morfológica, bastante más rica y de más antigua tradición en las regiones ibéricas que en las centropeninsulares, de lo que apenas podemos decir nada en estas últimas es de si estos característicos vasos estaban destinados a cubrir una multiplicidad de funciones o alguna muy concreta. Los caliciformes del ámbito ibérico hallados en contextos funerarios y cultuales, más numerosos, por cierto, que los procedentes de ambientes domésticos, a la inversa, por tanto, de la situación que observamos en el Duero, tradicionalmente se han visto como objetos destinados a cumplir varias funciones no excluyentes entre sí: recipientes destinados a las libaciones (de vino, leche, agua, hidromiel o de las cuatro sustancias, como refiere La Odisea al hablar del mago tebano Tiresias), contenedores de ofrendas sólidas, de frutos, simples objetos votivos per se (entre otros, GilMascarell, 1975: 321; Aparicio Pérez, 1976: 23 y 29; Id., 1997: 346; Pla Ballester, 1980: 270; Blázquez Martínez, 1983: 206; Marco Simón, 1983-84: 75-76; Martí Bonafé, 1990: 151-153 y

los castros y necrópolis vettonas o en yacimientos del área celtibérica como la necrópolis alcarreña de Luzaga, algunos con decoración incisa casi iguales a los nuestros (Díaz Díaz, 1976: 464-467, fig. 19, 1-5 y lám. V, 1 y 2). 


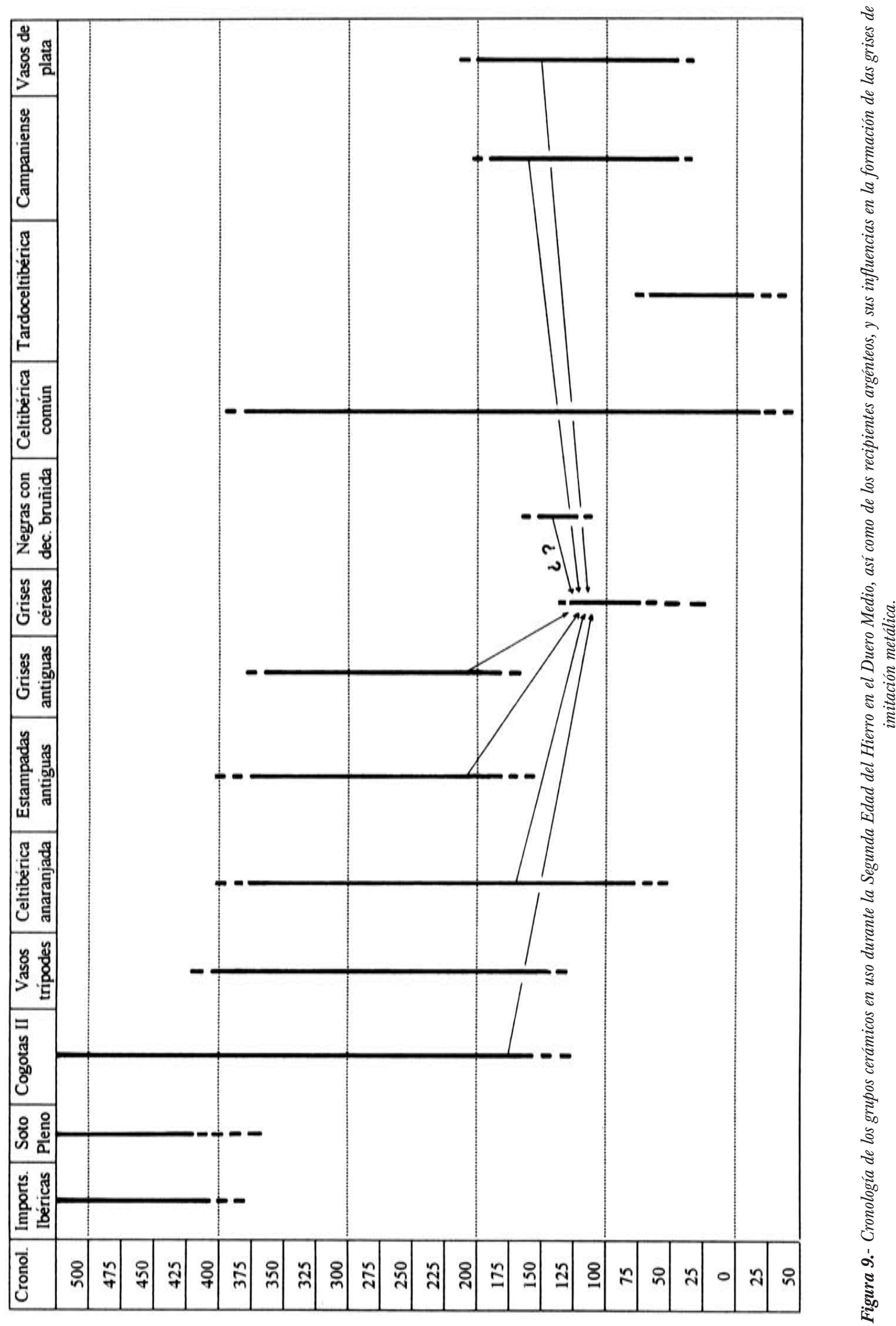


157-160; Ruiz, 1991-92: 85), etc. A todos estos posibles usos recientemente se ha añadido uno más: como portadores de ofrendas lumínicas (Martínez Perona, 1992: 271-275). Para los procedentes de medios habitacionales ibéricos hay autores que no ven clara su vinculación con el mundo religioso (Abad Casal, 1983: 194), estimando otros que pudieran haber sido lámparas de aceite con mecha flotante, uso que no deja huellas de fuego en su interior (Martínez Perona, 1992: 275).

\section{Forma XI: crateriforme (Fig. 2).}

Perfil muy próximo al de los caliciformes, se diferencia de aquéllos tanto en el tamaño como en media docena de rasgos morfológicos. En cuanto a la boca, no es totalmente abierta y acampanada como en aquéllos, sino con tendencia a cerrarse; el borde, también exvasado, es, sin embargo, más corto, con lo que adquieren un mayor protagonismo cuello y hombro; la anchura máxima ya no es la del diámetro de la boca, como veíamos en los caliciformes, sino que se sitúa en la parte media o media-alta, acentuándose de este modo la globulosidad del cuerpo; finalmente, no apoya en una base umbilicada como es habitual en aquéllos, sino realzada, de copa, al menos así es en el único ejemplar que se nos ha conservado prácticamente completo ${ }^{5}$. Como consecuencia del mayor cerramiento bucal, el bruñido apenas penetra por el borde interno, pero es de la misma calidad que el observado en cualquier otra forma.

A estas piezas se les suele designar en la bibliografía meseteña como grandes copas y en ocasiones como urnas, pero nosotros preferimos denominarlas crateriformes por derivar claramente de los vasos ibéricos así llamados debido a que copian modelos griegos y que encontramos muy extendidos por el levante y sur peninsular a partir del siglo IV a. C. (Pereira Sieso, 1987; Id., 1988: 162, fig. 12; Cuadrado y Quesada, 1989: 65-66, tipos 59 y 55, figs. 32 y 42; Mata y Bonet, 1992: 140, grupo VI, tipo 5, fig. 23; Sanz Gamo, 1997: 137), evitando de esta manera confusiones con las copas incluidas en la Forma III, con algunos morteros a los que también se les refiere a veces como copas y con las urnas propiamente dichas que constituyen nuestra Forma XII.

El vaso representativo del tipo es de procedencia caucense, muy proporcionado en sus

5. Los dos fragmentos que conforman la pieza ya en 1993 los publicamos, pero por separado (Blanco García, 1993b: fig. 3, 38 y fig. 7, 126). Al revisar para volúmenes, con un diámetro de boca de $18,1 \mathrm{~cm}$, una anchura máxima de 19,6 cm y altura situada entre los 23 y los $25 \mathrm{~cm}$, pues no sabemos con exactitud cuántos milímetros separan a los dos fragmentos. A pesar de contar con un campo decorativo idóneo para ser engalanado, se ha dejado liso por completo. En cerámica oxidante este es un perfil intermedio entre las formas IA y IB de la tipología de E. Wattenberg (1978: 22 y 43) y encuadrable entre las variantes 3-6 de la forma VII de Sanz Mínguez (1997: 287-289, fig. 211, y de perfiles más ajustados 148-149 nn. 149 y 153, fig. 151, 149 y 153), aunque estos modelos son más angulosos que el vaso caucense. Más cercana morfológicamente está, sin embargo, una gran copa que se recuperó en la necrópolis toledana de Las Esperillas (Urbina Martínez, 2000: lám. VII, 1), pero de cronología más antigua que la caucense. Todo ello evidencia que se trata de un tipo cerámico presente desde antiguo en el centro peninsular y que en el Valle del Duero, concretamente, se constata de forma más habitual en las comarcas centrales y meridionales -a los citados de Soto de Medinilla, Padilla de Duero y Coca podríamos sumar Simancas (Wattenberg Sanpere, 1978: 103, 66), Montealegre (Heredero García, 1993: 294, fig. 8, 3), Segovia (Zamora Canellada, 1975: 37, fig. 1, MS 8), Las Cogotas (Cabré Aguiló, 1932: lám. LI, 1 y 4), etc.-, que en las orientales.

Resulta muy sugerente la idea de que este gran vaso hubiera formado conjunto con alguno de los muchos caliciformes recuperados junto a él, en un contexto de consumo ritual de vino $\mathrm{u}$ otro líquido, tal como parecen haber sido usados los juegos formados por simpulum o cyathus $\mathrm{y}$ gran copa de La Custodia de Viana (Burillo Mozota, 1997: 237, fig. 8, sup. izq.). Sin embargo, no hay nada que nos permita establecer dicha relación, a pesar de que, como decimos, en el lugar de Los Azafranales en el que salió este vaso, en "Tierra de las Monedas I", se recuperaron fragmentos pertenecientes nada menos que a once caliciformes seguros (Blanco García, 1993b: fig. 3, 42 y 43, fig. 4, 45, 49 y 50, fig. 5, 54 y 56 , fig. $6,99,105,107$ y 110) y a otros dos más probables (Id., 1993b: fig. 6, 82, 108), ciertamente la mayor concentración de grises céreas hasta ahora conocida en Coca, pues en ella tampoco faltan los platos y fuentes, los cuencos, páteras y morteros, los perfiles en "S" y las urnas.

esta ocasión los materiales caucenses ha sido cuando nos hemos dado cuenta del error cometido, pues nos pasó desapercibido que pertenecían al mismo vaso. 


\section{Forma XII: urna (Fig. 2).}

En ella encuentran cabida todos aquellos vasos de boca tendente al cerramiento, borde vuelto, cuello más o menos desarrollado y cuerpo globular que además de ser referido por la bibliografía como urnas también lo son como orzas y ollas, aunque por estar destinados a usos de mesa ni los grises céreos ni los anaranjados muestran huellas de haber sido expuestos al fuego.

Cuatro son las variantes que se han podido deslindar, ninguna de las cuales nos es conocida en todo su perfil. Son piezas de tamaño mediano cuyos diámetros de boca oscilan entre 13,4 y 17,1 $\mathrm{cm}$, y al igual que los vasos caliciformes, suelen estar engalanadas con baquetones, acanaladuras y composiciones decorativas muy elaboradas siempre en los hombros, algunas de las cuales no es posible saber a cuál de las cuatro variantes corresponde (Fig. 4, 10, 13 y 17; Fig. 5, 37).

La Variante XII 1 la materializa un vaso procedente del nivel IX de la excavación Cuatro Calles de Coca del que sólo conocemos su tercio superior, pero suficiente para ver cómo algunos de sus rasgos le aproximan al crateriforme visto anteriormente. Se distingue por tener un borde exvasado corto dispuesto casi en ángulo recto respecto a la inclinación del cuello, formando una pequeña cornisa por tanto, y un amplio hombro recorrido por un baquetón sobre ancha acanaladura y otro resalte que no llega a ser baquetón pero que al igual que aquél ha sido decorado con grupos de trazos incisos paralelos entre sí, en oblicuo y con inclinación alternante (Fig. 4, 8). Su diámetro de boca es de $15,8 \mathrm{~cm}$, teniendo de anchura máxima $17,6 \mathrm{~cm}$.

La Variante XII 2 viene establecida por un vaso incompleto de la necrópolis vallisoletana de Las Ruedas recuperado en posición secundaria (Sanz Mínguez, 1997: 164 n. 317, 310, fig. 161, 317). Se caracteriza por tener borde vuelto engrosado, cuello y hombro desarrollados de tendencia troncocónica, y carena situada en el tercio inferior, donde se localiza la anchura máxima del vaso: $15,5 \mathrm{~cm}$ frente a los $14 \mathrm{~cm}$ que tiene de diámetro en la boca.

El único ejemplar representativo de esta variante, de pasta y superficies grises con acabado exterior lustroso, está ricamente decorado con un friso formado por grupos de cuatro rehundidos ovalados entre anillos impresos, delimitada la secuencia por dos baquetones y flanqueado todo el conjunto por dos collares de puntos impresos, el inferior horizontal y el superior aguirnaldado (Fig. 4, 21). Por todo esto, de momento hemos de considerar como decorada a esta variante.

En cerámica oxidante no conocemos ningún perfil exactamente igual al de este vaso que pudiera haber servido de modelo, aunque sí los hay parecidos en cuanto al tipo de borde, troncoconicidad del desarrollado hombro y anchura máxima próxima a la base, señalizada mediante carena o no. A estos parámetros responden, por ejemplo, un vaso numantino de menores proporciones que el vallisoletano (Wattenberg Sanpere, 1963: 212, 1162, tab. XLV, 1162), otro no tan esbelto como este último procedente de Los Cinco Caños de Coca pero pintado con motivos geométricos y zoomorfos en perspectiva cenital y datado también en el siglo I a. C. (Blanco García, 1997: 186 n. 2, fig. 2, 2 y lám. I, 2), o la urna completa del tesoro palentino de Las Filipenses (Raddatz, 1969: fig. 16, 1) del que, como más arriba hemos señalado, también formaba parte un fragmento de cerámica gris de imitación metálica identificado por C. Sanz, A. Gómez y J. A. Arranz (1993: 142). Curiosamente son, sin embargo, los ámbitos vettón y alcarreño los que nos brindan los más estrechos paralelos formales para la urna de Las Ruedas. En el primero de ellos, El Raso de Candeleda nos presenta una urna de perfil en casi todo igual, aunque de factura más tosca (Fernández Gómez, 1986: 749, fig. 446, Ca-3). También en la comarca de Molina de Aragón encontramos referencias morfológicas muy cercanas para el vaso en cuestión: p. ej., en la fase II del poblado de El Palomar, datada a mediados del siglo II a. C., se constató un perfil en casi todo igual pero con asa diametral (Arenas Esteban, 1999: 30, fig. 24, pieza inf. dcha.); la necrópolis de La Cerrada de los Santos o el poblado IV de La Torre (Id., 1999: 51, fig. 38, tumba 15 y 70, fig. 58, sups., fig. 59, sup. dcha., resp.), constituyen otros dos lugares alcarreños en los que comparecen tipos muy similares de urnas, fechadas aquí en los siglos III y II a. C., y todos adscritos a la forma regional X (Id., 1999: fig. 161). No sabemos a cuál de los dos ámbitos debe más la pieza de Padilla, pero de haber sido el castellano-manchego, vaso que por otro lado remite a prototipos claramente ibéricos (tipo 5.1 del grupo II de Mata y Bonet, 1992: 128, fig. 7), podría ser interpretados como un dato más a favor de las estrechas relaciones culturales que a través de los pasos de Somosierra, y vía Duratón, debieron de darse entre el Alto Tajo y la ribera padillense del Duero (Blanco García, 1998b: 164-171).

El vaso que marca la Variante XII 3 procede de Coca, tiene un borde vuelto engrosado de parecidas características al de la variante anterior pero con la peculiaridad de que de él arranca un 
asa diametral, cuello corto, amplio hombro bajo baquetón y cuerpo que apunta ser bastante globular (Blanco García, 1993b: 122, fig. 3, 33). Desconocemos qué tipo de base pudo tener, pero lo más probable es que fuera umbilicada (con o sin suave pie), como la de casi todos los vasos con asa diametral que conocemos. Tiene $17,1 \mathrm{~cm}$ de diámetro de boca y está decorado por medio de una hilera de puntos impresos sobre el baquetón y bajo éste un friso de palmetas sobre otra hilera de puntos (Fig. 5, 26), por lo que por ahora hemos de incluir esta variante entre los vasos decorados, a pesar de ser pieza única.

La Variante XII 4 también es caucense, caracterizándose morfológicamente por tener un borde exvasado sencillo poco proyectado al exterior, cuello apenas insinuado, hombro muy alto y cuerpo que se intuye de acusada globulosidad. Con tan sólo 13,4 cm de diámetro de boca, es el tipo de urna más pequeño de los cuatro. Su hombro aparece recorrido por dos resaltes muy juntos que han sido engalanados por medio de trazos incisos paralelos entre sí y dispuestos en oblicuo. Bajo ellos, un collar de puntos impresos (Fig. 4, 9). Una vez más, vemos cómo ésta es una variante decorada que, por otro lado, guarda cierta relación formal con una urna procedente de uno de los alfares de Carralaceña (Sanz Mínguez y Escudero Navarro, 1994: 165, fig. 2, 2).

\section{CONSIDERACIONES SOBRE LAS INFLUEN- CIAS MATERIALIZADAS EN LA CERÁMICA GRIS CÉREA.}

La dos primeras notas que saltan a la vista cuando se tiene ante sí la tabla de formas de este grupo cerámico gris de imitación metálica, y que no tienen nada de novedoso por cuanto ya han sido señaladas por otros autores y por nosotros mismos hace más de una década, son, por un lado, que el repertorio de perfiles es bastante menor del que encontramos en los corpora de cerámicas cocidas en atmósferas oxidantes -incluso varios tipos cerámicos, como el I 1 y 3, el II 3, el V 1, el VII 1, el IX 1, etc., sólo están representados por la única pieza que se conoce- ,y por otro, que prácticamente todo ese abanico formal ya existía en pastas rojas con anterioridad al 130/125 a. C., fechas en las que presumiblemente surge aquél. Sin embargo, esta segunda nota no nos da licencia para concluir que nuestras grises y negras son simples y mecánicas reproducciones en otro color de las cerámicas anaranjadas, pues la realidad es mucho más rica y compleja. Del análisis formal y ornamental llevado a cabo en las páginas precedentes cabe inferir que en esta especialidad vascular confluyen múltiples influencias procedentes de grupos cerámicos y recipientes metálicos que estaban en uso durante el siglo II a. C., y que si bien el grupo del que más deudor parecen ser desde el punto de vista morfológico fue, sin duda, el de esas cerámicas finas cocidas en atmósfera oxidante -las denominadas de manera inapropiada como "estrictamente celtibéricas"-, en mayor o menor medida otros también dejaron su huella en las mismas (Fig. 9).

Empecemos por éste, por el de la celtibérica de pastas rojas. Para algunas formas y variantes grises sus modelos en cerámica anaranjada se remontan nada menos que a los comienzos de la producción regional de vasos a torno y que, sin apenas variaciones, llegaron a la etapa Celtibérica Tardía, pero para otras sus prototipos no son tan antiguos, sino más recientes y evolucionados. En efecto, por ser formas que apenas experimentaron variaciones a lo largo del tiempo, platos de los tipos I 2 y I 5 ya los encontramos, p. ej., entre las producciones del alfar vacceo de Coca en su Fase I (Blanco García, 1998a: 124-125, fig. 3, 4 y fig. 4, 10). De igual modo, en estas mismas instalaciones que cabe fechar a mediados del siglo III a. C. pero que quizá pudieran ser algo más antiguas, ya comparecen las copas de tipo III 4 (Blanco García, 1998a: 126, fig. 6, 7) y los perfiles en "S" VIII 3 (Blanco García, 1998a: 126, fig. 6, 11). Pero más numerosas que en esos momentos antiguos las tenemos en pleno siglo II a. C. como inmediatas antecesoras de las grises. No vamos a insistir en lo que las producciones oxidantes celtibéricas han aportado a las grises por haber concretado al analizar cada una de las formas.

Otro grupo cerámico que dejó su huella indeleble en estas producciones leucofeas fue el de Cogotas II, vigente en la zona vettona y en el Duero medio desde el siglo VI a. C. hasta muy avanzado el II a. C., momentos estos últimos en los que se produce el contacto cronológico con las grises céreas. Los elementos en los que vemos materializadas estas influencias son de carácter ornamental más que formal:

$1^{\mathrm{O}}$ de manera general, en el barroquismo con el que se han engalanado los tipos propiamente decorados como son los caliciformes y las urnas (Figs. 4 y 5). Un barroquismo que sin duda absorbieron de las producciones cogotianas de las últimas etapas y del cual no cabe hacer responsable únicamente a los vasos argénteos por cuanto, en general, son bastante más sobrios y cuya más notoria contribución a este recargamiento ornamental fue el baquetón, bien liso bien recorrido por grupos de líneas inclinadas impresas general- 
mente de dirección alternante. No se puede ocultar que algunos vasos de plata peninsulares además de estos baquetones tienen como complementos decorativos series de ovas y eses encadenadas, guirnaldas, reticulados, triglifos y metopas, collares de puntos, triángulos de granete, series de MWMW de vástago central lanceolado como los que vemos en Chão de Lamas, etc. (Raddatz, 1969), sin embargo, muy pocos de estos elementos encontraron reflejo en las cerámicas grises. Incluso los baquetones localizados a mitad del cuello acampanado tan frecuentes en los vasos de plata (p. ej., los de Padrão: Beirão y Gomes, 1985: 482, est. VII, A) no aparecen en los cerámicos.

$2^{\mathrm{O}}$ en la utilización que se hace de los rehundidos o cazoletas hemisféricas, ovaladas, biapuntadas, etc. (Fig. 3, grupo 3), distribuidas bien individualmente y a distancias fijas unas de otras, bien en grupos de dos, tres, cuatro, seis e incluso ocho impresiones (Fig. 4, 11-14 y 21, Fig. 5, 25, 27, 32 y 38 , un procedimiento decorativo del que, salvo alguna rara excepción, prácticamente no se hizo uso en los vasos argénteos.

$3^{\circ}$ igualmente, la huella de aquellas tradicionales cerámicas meseteñas la vemos en el uso de grupos de acanaladuras verticales, paralelas entre sí o suavemente convergiendo hacia la base, pero ahora sólo en número de tres o de seis y en ocasiones flanqueadas por series de puntos impresos, también muy propio de aquellas especies (Fig. 4, 15-18 y Fig. 5, 34) y que en absoluto encontramos en los recipientes de plata. Más propias de éstos, aunque sólo se constatan en unos pocos, son las acanaladuras horizontales que corren paralelas a los baquetones, utilizadas como complemento decorativo para resaltar el volumen.

$4^{\mathrm{O}}$ en el importante empleo que se hizo de punzones y matrices, a la sazón más propios de los ceramista que de los orfebres. En efecto, desde los simples anillos impresos hasta las palmetas más elaboradas, pasando por los arcos y círculos cuartelados, los trisqueles o los helicoides (Fig. 3, grupo 5), las estampillas llevadas a la cerámica gris son de raigambre básicamente cogotiana, no tienen reflejo en los vasos de plata, aunque, todo hay que decirlo, la inspiración mediterránea de muchas de aquéllas y de éstos constituye el punto en el cual confluyen ambas especialidades artesanales. Y no es que existiera imposibili- dad técnica alguna para que los plateros incorporasen a sus recipientes estampaciones a troquel, pues en algunos ejemplares están presentes y en las producciones broncíneas, p. ej., se empleaban de manera habitual, sino que parece existir una tendencia consciente a hacer escaso uso de ellas en la platería. Por tanto, en las cerámicas grises se produce una curiosa convivencia entre las técnicas, métodos de trabajo y gustos empleados por la artesanía del alfarero y la del orfebre.

$5^{\mathrm{o}}$ ya de manera secundaria, en las calidades bruñidas de coloración negro intenso, acharoladas, que encontramos en algunos de nuestros vasos grises también nos parece otro aspecto en el que se manifiestan las influencias de la cerámica de Cogotas II, aunque por remota que pueda parecer, en esta cuestión creemos que hay que dejar una puerta abierta a la posibilidad de que también pudieran haber tenido algo que ver los espesos barnices de la cerámica campaniense.

A pesar de este importante fondo de origen cogotiano en las cerámicas grises, curiosamente a ellas no fueron trasladadas sus decoraciones más características, esto es, las pectiniformes. De manera excepcional, quizá quepa interpretar como imitación de peine impreso el friso que vemos en un fragmento de La Mesa de Miranda (Cabré, Cabré y Molinero, 1950: lám. XIX, 10), pues más que impresiones de peine parecen líneas de puntos en zig-zag, ya que éstos no están secuenciados igual en todas ellas (Fig. 4, 6). En un yacimiento también abulense como es el poblado de El Raso, ubicado ya en la Cuenca del Tajo, encontramos un caso muy similar: un caliciforme completo de la forma X con rosetas estampadas entre pares de líneas dispuestas en zig-zag hechas a base de puntos cuadrangulares impresos que nos recuerdan de nuevo el peine impreso (Fernández Gómez y López Fernández, 1990: fig. 6, 44-85 y fig. 8, 6.1). Otros dos ejemplos excepcionales más de imitación los encontramos en Fuentes de Ropel y Coca, donde, respectivamente, grupos de líneas incisas y espatuladas que ornan sendos fragmentos parecen querer recordar peinados cogotianos (Celis Sánchez, 1990: 473-474, fig. 9, 5; Blanco García, 1993b: 120, fig. 2, 21), si bien no son tales. Esta falta de decoraciones propiamente pectiniformes no creemos que se deba interpretar como una carencia si pensamos en que las decoraciones barrocas de Cogotas II perviven hasta avanzado el siglo II a. C. Más bien parece tratarse de un modo de proceder plenamente consciente 
según el cual como la principal pretensión en los vasos grises decorados era conseguir un efectismo de claroscuro y esto es algo que las finas incisiones o los pequeños puntos apenas producen, por ello se desestiman, recurriendo de este modo a las estampillas, los gruesos puntos y los rehundidos de variada morfología, en unión de baquetones, carenas y acanaladuras. En definitiva, frente a la impresión de monotonía cromática que producen las formas lisas de este grupo cerámico gris, las decoradas adoptan del abanico vascular vigente sólo aquellos elementos ornamentales que permiten el que se produzca un juego de luces y sombras similar al conseguido en los recipientes argénteos.

Debido a que la caliciforme fue una de las primeras formas en cerámica gris cérea identificadas por la investigación al ser la más numerosa y común en los yacimientos (Fig. 6), que destacaba por su excelente calidad técnica, su coloración gris uniforme, el esmerado tratamiento de las superficies externas que hacía pensar en prototipos metálicos y sus peculiaridades decorativas, automáticamente, y con acierto, se la consideró imitación en barro de los vasos argénteos en forma de cáliz hallados en conocidos tesoros peninsulares como los de Salvacañete, Tivisa, Chão de Lamas, Arrabalde, Padrão, etc. Con el tiempo, esta circunstancia ha conducido a la investigación a considerar a todo el grupo cerámico como emulador exclusivo de los citados recipientes de plata, afirmación sobre la que conviene hacer algunas matizaciones.

En principio, la condición de modelo morfológico que tuvieron los vasos caliciformes de plata creemos que habría que aplicarlo exclusivamente a la forma $X$, evidentemente, $y$ de manera secundaria quizá a la XI y la XII, pues si bien muchos de los rasgos formales de estas últimas no los encontramos en aquéllos, los procedimientos decorativos basados en los baquetones impresos y las acanaladuras, sí. En el resto de formas, de la I a la IX, las influencias de tales recipientes debieron de materializarse por derivación, a través ya de los propios vasos cerámicos de las citadas formas X-XII y como fruto de la experiencia en trasladar unas calidades metálicas a las mismas que, por otra parte, no era nueva para los alfareros meseteños. Puesto que en sentido estricto carecemos de formas prototípicas en plata que nos sirvan de referencia para la mayor parte de los perfiles que hallamos en cerámica gris (fuentes, copas, morteros, cubile-

6. Lamentablemente, en los niveles implicados están ausentes materiales metálicos, vítreos o simplemente tes, boles, perfiles en "S", oinochoes, e incluso para los crateriformes y urnas), lo lógico es pensar que en aquel metal seguramente nunca debió de existir un repertorio tipológico tan variado en los siglos II-I a. C., y lo que se hizo fue simplemente aplicar las técnicas de producción de los caliciformes cerámicos a otras formas que, en arcillas rojas, estaban en uso en los momentos en los que surgen las grises. Curiosamente, existen formas en plata que, al menos por ahora, no tenemos constatadas en barros grises céreos, como, por ejemplo, los cuencos del tesoro de Padrão (Beirão y Gomes, 1985: 482 y ss., est. VII A). A lo que vamos: cabe la posibilidad de que la forma X y a seguido la XI y la XII fueran las primeras que empezaran a fabricarse por parte de los alfareros -buscando transportar a una materia tan barata como la cerámica las características físicas de la vajilla argéntea y tal vez los contenidos ideológicos que en ella se depositan-, y ante la demanda que para tan atractivos productos cabe suponer, sus calidades se fueran extendiendo poco a poco a otras formas habitualmente elaboradas en pastas oxidantes, con lo que de este modo se iría configurando el repertorio tipológico tal como hoy lo conocemos. Esta, que sólo es una hipótesis, pero muy verosímil a nuestro parecer, de cómo pudo evolucionar internamente el grupo cerámico, pues no parece que naciera de golpe con la amplitud formal observada, está construida básicamente sobre los datos obtenidos de las secuencias estratigráficas de Coca pero también sobre otros indicios tales como el carácter de precedente que parecen tener los caliciformes fabricados a mano de Las Quintanas y el Cerro de la Gavia, arriba citados. Por la trascendencia del problema, de carácter crono-tipológico, creemos conveniente detenernos unos instantes en él.

Analizando las secuencias estratigráficas documentadas en algunos de los sondeos practicados en Coca observamos cómo, con ligeras variaciones, se repiten una y otra vez las mismas series de asociaciones cerámicas significativas ${ }^{6}$, que recogemos en el cuadro de Fig. 7. de es:

Muy resumidamente, lo que de él se despren-

$1^{\mathrm{o}}$ que si bien en casi todos los sondeos el nivel más antiguo con grises nos presenta ya un repertorio de entre tres y seis formas, en alguno es la de cáliz la primera que se constata. Cierto es que esta es la forma que a lo largo del tiempo más se

numismáticos que nos ayuden a concretar mejor los datos que ofrecen las asociaciones cerámicas. 
fabricó y por simple cálculo de probabilidades lo lógico es que estuviera presente desde los niveles más antiguos, pero por todo un conjunto de indicativos que en los puntos que siguen iremos degranando creemos que fue la que inició estas producciones.

$2^{\mathrm{o}}$ que en todos los sondeos el único vaso que siempre está presente ya desde el primer nivel en el que se registran las cerámicas grises es el caliciforme, además en cierto número respecto a los otros tipos y siempre conviviendo con los anaranjados pintados, los cuales, por otra parte, también suelen comparecer en número destacado y desde niveles más antiguos que aquéllos, por lo que tienen la misma condición de prototipos que atribuimos a los argénteos. Estos caliciformes en pastas rojizas previos al surgimiento de los grises casi siempre están conviviendo con cerámicas a mano de Cogotas II, nota que refuerza una vez más algo comprobado desde antiguo en Coca y otros muchos yacimientos del Valle del Duero: que estas producciones manuales perviven hasta muy avanzado el siglo II a. C. Ilustrativo a este respecto es la tumba 3 de Las Ruedas, en la que conviven vasos a mano con un caliciforme gris y otro anaranjado (Sanz Mínguez, 1997: 54, fig. 20).

$3^{\circ}$ que tanto los caliciformes grises como los oxidados pintados se mantienen a niveles numéricos parecidos a lo largo de las respectivas secuencias, por lo que aquéllos constituyeron la forma más vital del grupo, extremo que se ve reflejado también en los cálculos de cuantificación que hemos realizado (Fig. 6).

$4^{\mathrm{O}}$ que los caliciformes en pastas oxidadas, superficies bruñidas hasta conseguir un tacto céreo y decoración impresa, en todo iguales a los grises objeto de nuestra atención, son al menos tan antiguos como éstos y probablemente marcharon juntas ambas producciones hasta su extinción.

$5^{\mathrm{o}}$ que, salvo en T.M. I, donde están presentes desde el primer momento, y en Avda. de la Constitución n. 8, donde no aparecen, los vasos de cocción oxidante decorados con pinturas blancas a partir de cierto momento comienzan a convivir con las cerámicas grises. Esto tiene tres lecturas posibles: que estas pinturas blancas sean más antiguas de lo que tradicionalmente se viene sosteniendo (segunda mitad del siglo
I a. C.) y haya, por tanto, que retrotraerlas, al menos las iniciales, como poco al primer cuarto de dicha centuria; que nuestras grises de imitación metálica siguieran estando en uso durante buena parte de la segunda mitad de la misma; que, en tercer lugar, se dieran ambas situaciones, pues no son incompatibles entre sí. Cada vez nos caben menos dudas de que la referida en segundo lugar fue un hecho cierto, lo cual nos obliga a distinguir dos periodos en la vida de estas cerámicas grises: uno de producción y uso que se extendería entre 130/125 y 75/70 a. C. y otro, subsiguiente, en el que ya no hay producción pero, con carácter residual, continúan estando en uso hasta su amortización y extinción. Algo parecido a lo que ocurrió siglos después con la TSHT, que a mediados del siglo $\mathrm{V}$ d. C. deja de producirse pero la seguimos encontrando con igual carácter residual y como producto de lujo en poblados y necrópolis visigodos. Uno de los pilares en los que se sustenta esta idea deriva de la observación de que allí donde coexisten vasos grises y oxidantes con pinturas blancas aquéllos casi siempre poseen palpables signos de haber sido usados durante mucho tiempo (rozaduras y golpes múltiples, desgastes por el uso, etc.). La U.E. 166 de la intervención de 1999 -una auténtica scherbenkonzentration de las que habitualmente se registran en grandes oppida centroeuropeos como, p. ej., el de Manching (Sievers et alii, 2000: 366-367, fig. 6), y que podría tener un carácter de deposición votiva, aunque con características distintas a las conocidas de Garvão (Beirão et alii, 1985; Id., 1985/86), El Amarejo (Broncano Rodríguez, 1989), Capote (Berrocal-Rangel, 1994) o incluso Cuéllar (Barrio, 1999: 183; Id., 2002), entre otras- ha sido concluyente a este respecto: el conjunto de recipientes grises recuperado en un hoyo, de más de 1,5 m de diámetro y casi $1 \mathrm{~m}$ de profundidad, que estaba sellado por arcilla en el que también comparecían vasos polícromos con pintura blanca y otros muchos elaborados en cerámica común, a pesar de estar formado por piezas prácticamente completas aunque fragmentadas, su nivel de desgaste era tal que sólo un uso muy dilatado podía haberlo producido (parte del mismo en Pérez González y Blanco García, 2000: 38-39). Dicho sea de paso, la pervivencia de estas producciones hasta 
muy avanzado el siglo I a. C., como nosotros creemos, explicaría por qué en Rosinos de Vidriales aparecen unas cerámicas ya romanas de inicios del I d. C. que Santiago Carretero cree inspiradas en estas grises céreas pero que no ve nada clara por la falta de conexión cronológica entre ambas especies (Carretero, 2000: 617-622, fig. 311, 10-11 y fig. 312, 13 y 14). Con nuestra propuesta el problema quedaría resuelto. Como refuerzo de esta idea, hemos de decir que vasos grises similares a los de Rosinos también comparecen en Los Mercados de Duratón, en contextos claramente fechables a comienzos del I d. C. por su asociación a itálica y sudgálica, y en los que están presentes algunos fragmentos de grises céreas (todo inédito).

Recuperando el hilo de cuanto veníamos diciendo sobre la vajilla argéntea, el que Coca sea el yacimiento en el que por ahora mejor están representadas estas cerámicas grises, tanto cuantitativamente como por lo que respecta a la amplitud del repertorio formal, unido al hecho de que una de sus fuentes principales de inspiración fuera esa vajilla, al menos en lo que se refiere a las calidades cromática y táctil de todo el grupo así como a la morfología y sistemas decorativos de algunos tipos concretos, nos hace suponer que en los siglos II y I a. C. en él debió de existir una cierta riqueza en recipientes de dicho metal. Aunque no los citan de manera expresa, en las mismas fuentes escritas encontramos referencias a esa importante riqueza en plata que existió en $\mathrm{Coca}^{7}$, pues cuando el año 151 a. C. L. Licinio Lúculo requiere de los caucenses nada menos que 100 talentos del preciado metal -algo más de $2600 \mathrm{~kg}$, que traducido a moneda serían unos 600.000 denarios- como uno de los requisitos indispensables para evitar ser atacados y aquéllos realizan el pago (App., Iber., 52), eso quiere decir que poseían incluso más de lo que el general romano había pedido. Y casi tres toneladas de plata es mucha plata $^{8}$, no sabemos si perteneciente al erario público, como propone M. P. García Bellido (1999: 385) para todos estos depósitos ciudadanos de riqueza ansiados por los generales romanos, al patrimonio privado de las clases más pudientes, o a ambos titulares, pero en cualquier caso atesorada durante décadas como fruto tanto del comercio como de la rapiña llevada a cabo sobre pueblos vecinos y del cobro de servicios prestados como mercenarios por hombres de armas caucenses en los ejércitos ibéricos, cartagineses e incluso romanos. No por casualidad Lúculo, ansioso de gloria militar y de botín como estaba -a pesar de ser uno de los hombres más ricos del Estado romano-, se plantó frente a las puertas de Cauca como primera ciudad a saquear del Valle del Duero antes que entrar en otras que, desde la zona carpetana de la cual procedía, las tenía más cerca o a distancias similares (p. ej., Segovia, Tormejón, Sepúlveda o Cuéllar ${ }^{9}$ ). A diferencia de sus vecinos orientales y semejanza de los que por el oeste y norte tenían, los vacceos preferían atesorar la plata en joyas, vajilla y pequeños lingotes más que en moneda circulante, descartando con rotundidad acuñarla ellos
7. Y que con las fuentes en la mano, no parece que debamos hacer extensiva al resto de ciudades meseteñas, pues nos parece sintomático que a lo largo del proceso de conquista muchos generales romanos en las negociaciones de rendición de varias de ellas no reclaman la entrega de metales preciosos. Eso es que sus informadores les habían advertido que no los tenían. Pensemos, por ejemplo, en los casos de Intercatia y Numancia, pues de creer a Appiano (Iber., 54) los habitantes de la primera carecían de oro y plata porque no les daban valor, y los segundos del 133 tenían tan escaso metal precioso, según Plinio (Nat. Hist., 33, 141), que Escipión sólo pudo gratificar con siete denarios a cada uno de sus soldados, lo cual no nos parece meramente coyuntural pues siete años antes Q. Pompeyo no pudo obtener de ella más que 30 talentos, además pagados en dos plazos (App., Iber., 79). No tenemos porqué dudar de la veracidad de estos datos textuales, ni de si son reflejo o no de la pobreza metálica que padecían muchas poblaciones, pues con anterioridad a los momentos a los que van referidos quizá hubieran tenido importantes patri- monios en tales especies y por circunstancias (militares, subsistenciales, etc.) se hubieran visto en la necesidad de desprenderse de ellos, pero lo cierto es que parecen existir enormes desequilibrios entre unas ciudades y otras en cuanto al volumen de oro y plata atesorado.

8. Piénsese, por ejemplo, que cuando el cónsul M. Porcio Catón unas décadas antes pide ayuda a guerreros de Celtiberia para defenderse de "un gran ejército de bárbaros", aquéllos le piden 200 talentos de plata (Plut. Cat. Ma., 10, 1-2). O que M. Claudio Marcelo en el año 152 obtuvo nada menos que de tres entidades étnicas como eran los belos, titos y arévacas 600 talentos, una cifra considerada más que suficiente para financiar la guerra (Posid., frgto. 91 y Str., III, 4, 13).

9. Si aceptamos con J. Barrio que este poblado se deshabita a finales del siglo II a. C. o comienzos del I (Barrio Martín, 1993: 212; Id., 1999: 156; Barrio Martín y Alonso Mathias, 1999: 297) y no un siglo antes como estiman otros autores y hacen extensible a su necrópolis (Sanz Mínguez, 1997: 247-248, 314, 332 y 439; Id. 1999: 252). 
mismos ${ }^{10}$, por lo que las clases altas caucenses del siglo II a. C. debieron de estar muy acostumbrados a disponer de vasos argénteos como los que vemos en conocidos tesoros peninsulares. Sin embargo, y dejando aparte la moneda, aunque en plata sí tenemos constatados en Coca algunos lingotitos cizallados quizá de esa época (inéditos) $\mathrm{y}$ un pequeño broche o hebilla de dos garfios inicialmente interpretada como colgante (Blanco García, 1988: 46), que nosotros sepamos hasta ahora no ha aparecido ni un solo vaso del referido metal que podamos poner en relación con todo ese fondo de bienes de prestigio ( $\mathrm{y}$ tal vez simbólicos) argénteos y con las cerámicas grises que poco tiempo después hicieron de ellos sus modelos. Como no creemos que Coca quedara totalmente deshabitada tras el choque del 151 y hasta el 134 a. C. en que P. Cornelio Escipión "permite la vuelta de los caucenses a su ciudad y a sus casas" (App., Iber., 89), es posible que ese gusto tradicional por los recipientes de plata $\mathrm{y}$ esa memoria de las riquezas perdidas tuviera algo que ver con el nacimiento poco después de la especialidad cerámica considerada. Tal vez las funciones que aquéllos cumplían siguieron vigentes, y al no poderse llevar a cabo en vajilla de plata, como mal menor se utilizasen vasos cerámicos de parecido aspecto. Ligado a estas ideas que nos gustaría menos conjeturales, parece probable que si en las tierras del centro peninsular los vasos de plata se han hallado en tan escaso número para las cantidades que intuimos debieron de existir en los siglos II y I a. C., con toda seguridad ello se debe a que no han pervivido hasta hoy bien por haber sido fundidos y transformados a lo largo del tiempo en otros objetos, bien por haberse vendido o intercambiado por otros productos, bien por haber sido requisados, como ocurrió en Coca en el año 151 a. C. y quizá también en el 74 a. C. cuando Cn. Pompeyo Magno toma y saquea de nuevo la ciudad (Front., Strat., II, 11, 2), etc.

Siguiendo ahora con otras especies cerámicas vinculadas a la génesis de las grises céreas, su parte de responsabilidad, aunque sensiblemente menor que las producciones vasculares oxidantes, cogotianas y argénteas, tuvieron también las

10.Si en el sistema de organización política y económica de las más ricas y populosas ciudades vacceas como Pallantia, Cauca, Rauda o Pintia, p. ej., no se contempló la acuñación de moneda de plata pero sí el uso y atesoramiento de las que emitían otros pueblos, no creemos que se debiera a la falta del citado metal sino probablemente a que estas gentes del Duero Medio quizá les pareciese dilapidar la riqueza el convertirla en moneda, pues al torneadas decoradas con estampillas y las denominadas grises antiguas, especialidades ambas que para un mejor análisis hemos desgajado de las troncales en las que pueden ser incluidas y cuyas cronologías se centran en la segunda mitad del siglo IV y todo el III a. C. pero que creemos penetraron en el II a la par que lo hicieron las manuales de Cogotas II, como numerosos autores sostienen (p. ej., Martín Valls, 1986-87: 73; Álvarez Sanchís, 1999: 204) o ampliamente se evidencia en el poblado de El Raso, habitado desde mediados del siglo III a. C. hasta época cesariana, situación que Sanz Mínguez rechaza (1999: 260) al fijar su atención no en el citado enclave abulense sino en la necrópolis del mismo nombre pero cronología más antigua, pues se abandona a mediados del siglo III a. C. Si bien lo poco que parecen haber aportado las estampadas hechas a torno fue de carácter decorativo algunos tipos de estampilla que, aunque también están presentes en los vasos manuales de Cogotas II, suelen ser más propias de los torneados, como las aspas o las rosetas multipétalas-, lo atribuible a las grises antiguas tiene que ver con la morfología, en concreto con los vasos caliciformes, pues no creemos que la referencia exclusiva de los fabricantes de las grises tardías que nos ocupan fuesen los vasos argénteos. Somos de la opinión de que debido a que ya existía una tradición en modelar caliciformes en pastas grises, tanto a mano como a torno, por parte sobre todo de los alfareros del ámbito vettón pero que luego se trasladó al Duero central (p. ej., Cabré Aguiló, 1930: lám. LXIV; Fernández Gómez, 1986: 578 n. 6, fig. 316, 6; sepulturas 542, 777, 1155, 1379, 1433, etc. de La Osera ${ }^{11}$ ), esa tradición pudo perfectamente converger con las influencias ejercidas por los vasos de plata y resultar nuestra forma X.

En un contexto en el que en todo levante y sur peninsular la industria alfarera del Ibérico Tardío se muestra permeable a las influencias de la campaniense A y B (Beltrán Lloris, 1978: 58; Berrocal-Rangel, 1989-90: 119; Id., 1998: 115; Mata Parreño y Bonet Rosado, 1992: 140; Cela Espín, 1994: 178; Bonet Rosado, 1995: 399; Principal-Ponce, 1998: 17 y 162-164; Bonet

entrar en los circuitos comerciales sus emisiones otros podían atesorarla como estaban haciéndolo ellos. De esta forma, podríamos estar ante una especie de "mentalidad mercantilista" vaccea que no es el único pueblo peninsular que en la Antigüedad la practicó y que en otras partes del Mediterráneo también se constata.

11. Datos amablemente facilitados por I. Badequeno, a quien le estamos muy agradecidos. 
Rosado e Izquierdo Peraile, 2001: 279-282, entre otros), y en el que esta oleada alcanza con cierta intensidad al conjunto de la cerámica celtibérica de época tardía, como han manifestado diversos autores (Lorrio, 1989: 252; Martín Valls y Esparza Arroyo, 1992: 261) y quedado patente tras los análisis de las producciones de cinco de los más importantes yacimientos del Alto Duero, concretamente las que se fechan entre los años 133 y 75 a. C. (García Heras, 1998: 25), las grises de imitación metálica no iban a ser una excepción. Son sobre todo en las formas I y III en las que nos parece apreciar rasgos derivados de dichas cerámicas más que de la tradición autóctona. A esto hay que añadir la posibilidad de que algunas palmetas impresas se hubieran inspirado también en aquellas cerámicas, aunque extraña ver cómo no comparecen en el interior de platos, cuencos y copas, como vemos en ellas y lo cual ya sería un rasgo definitivo para consolidar esta idea, sino en los hombros de caliciformes y urnas. A pesar de ello, y tal como nosotros lo entendemos, la idea de absorción de rasgos propios de la campaniense no sólo es perfectamente compatible con la que pone todo su énfasis en las influencias que los vasos argénteos ejercen sobre las producciones grises en general, sino que nos parece complementaria. Parece lógico pensar que los vasos campanienses no pudieron estar considerados por sus usuarios al mismo nivel que los recipientes de plata en cuanto al significado simbólico que éstos debieron de tener y su carácter de lujosos bienes de prestigio, pero qué duda cabe que a los ojos de los autóctonos la vajilla itálica (o la fabricada ya en la Península) debió de gozar también de cierto prestigio. Prestigio derivado no sólo de su condición de producto exótico, sino también de la calidad física del mismo y su rareza, pues a pesar de que aún son pocos los hallazgos de cerámica campaniense constatados en el Valle del Duero se encuentran repartidos por casi todo él, sobre todo por los rebordes oriental y meridional, lógicamente ${ }^{12}$. La nómina de lugares en los que están presentes, nada despreciable, va creciendo cada año y a los citados

12. No obstante, de las cerámicas campaniense hasta ahora constatados en la Meseta Norte sólo podrían haber influido en las grises, teóricamente, aquellos que se fechan en las etapas Media/Clásica y primera mitad de la Tardía de la periodización de M. Py para la campaniense A (Py, 1993: 146), esto es, entre el 180 y el 70 a. C., no los posteriores, lógicamente. Hallazgos, por tanto, como los de Sasamón, que se fechan a fines del siglo I a. C. (Abásolo y García, 1993: 101), y que incluso puede que sean imitaciones, no ejercerían influencia alguna por Martín Valls y Esparza Arroyo (1992: 272) de Izana, Numancia, Roa, Osma, Coca, Las Cogotas, La Mesa de Miranda, La Osera, Padilla de Duero y Salamanca hay que añadir otros muchos hallazgos, unos antiguos como los de Muro de Ágreda (Taracena, 1941: 119; Jimeno Martínez, 2000: 253) o el Cerro de la Virgen de Tormejón (Lucas y Viñas, 1971: 80-81, fig. I, 6), pero otros nuevos, procedentes tanto de varios de los yacimientos arriba citados como de otros en los que hasta ahora no estaban presentes: El Castillejo de Garray (Morales Hernández, 1995: 132, fig. 55), el campamento $\mathrm{V}$ de Renieblas (Sanmartí Greco, 1992: 420-422, fig. 3), Herrera de Pisuerga (tres fragts. inéditos), Astorga (dos fragts. inéditos), Sasamón (Abásolo y García, 1993: 45 nn. 129-131 y 101), o la caucense Cuesta del Mercado (Blanco García, e. p.) ${ }^{13}$.

En último término, creemos conveniente dedicar siquiera unas líneas a cierto grupo de vasos presumiblemente torneados de color intensamente negro y decoración bruñida que recientemente ha sido aislado en la necrópolis de Las Ruedas y parece tener representación también en Cuéllar. Inicialmente considerada esta especialidad alfarera como coetánea de las grises céreas (Delibes et alii, 1995: 111), en un segundo momento se ha postulado de manera provisional una fecha de inicio algo más antigua (Sanz Mínguez, 1997: 161-162 y 312-314, fig. 160 y XXVII), de hacia la mitad del siglo II a. C., arrancando por tanto de momentos anteriores a las grises objeto de nuestra atención pero solapándose con ellas en su fase avanzada, por lo que de ser esto cierto pudo haberse dado una situación de interinfluencias. Si es así y, efectivamente, nacen antes que las grises, como entre sus perfiles ya encontramos tanto los caliciformes como las urnas globulares, eso querría decir que, al igual que otros grupos ya referidos, este también tendría la condición de prototípico, a pesar de que algunas de sus formas no existen por ahora en pasta gris y, de manera extraña, en Coca aparentemente están ausentes, cuando es el yacimiento con la mejor colección de grises céreas de

13. El hallazgo de El Calvario, en Peñalba de Castro, citado por Jaeggi (1999: 244, map. 7) basándose en Beltrán Lloris (1980: 220) carece de validez para nosotros por cuanto no corresponde a la localidad burgalesa, sino a la oscense Puebla de Castro, también erróneamente recogido con aquel nombre por el investigador aragonés aunque, eso sí, dentro de Huesca. 
toda la Submeseta Norte. En este mismo sentido morfológico, resulta muy atractivo pensar que una forma tan extraña al repertorio vascular argénteo y tan poco pródiga en cerámica celtibérica oxidante como es la XII, hubiera derivado de las de este grupo negro, a su vez asimilador de elementos decorativos procedentes de las mismas especies que influyeron en las céreas. En definitiva, este grupúsculo de cerámicas negras contribuye a enriquecer más si cabe la problemática de las grises de imitación metálica, pero ante lo mucho que de él aún desconocemos lo único que por el momento se puede hacer es esperar a obtener confirmación de la cronología propuesta e ir completando su repertorio formal y así poder valorar más adecuadamente las posibles relaciones que pudieron tener ambas producciones.

\section{Bibliografía}

\section{Abreviaturas}

AAH Acta Arqueológica Hispánica. Madrid.

AEspa Archivo Español de Arqueología. Madrid.

AIEZFo Anuario del Instituto de Estudios Zamoranos 'Florián de Ocampo'. Zamora.

APA Anales de Prehistoria y Arqueología. Murcia.

ApAa Atlas de Prehistoria y Arqueología Aragonesas. Zaragoza.

APL Archivo de Prehistoria Levantina. Valencia.

AA Acta Salmanticensia. Salamanca.

BAEAA Boletín de la Asociación Española de Amigos de la Arqueología. Madrid.

BAH Bibliotheca Archaeologica Hispana. Madrid.

BAR British Archaeological Reports. Oxford.

BMAN Boletín del Museo Arqueológico Nacional. Madrid.

BPH Bibliotheca Praehistorica Hispana. Madrid.

BraH Boletín de la Real Academia de la Historia. Madrid.

BSAA Boletín del Seminario de Estudios de Arte y Arqueología. Valladolid.

CNA Congreso Nacional de Arqueología. Zaragoza.

Cupauam Cuadernos de Prehistoria y Arqueología de la Universidad Autónoma de Madrid. Madrid.
DocAmérid Documents d’Archéologie Méridionale. Lattes.

EAE Excavaciones Arqueológicas en España. Madrid.

Es Estudios Segovianos. Segovia.

HA Hispania Antiqua. Valladolid.

MemjSEA Memorias de la Junta Superior de Excavaciones y Antigüedades. Madrid.

MF Madrider Forschungen. Berlín.

Mна Memorias de Historia Antigua. Oviedo.

Mм Madrider Mitteilungen. Heidelberg/Mainz am Rhein.

MmaV Monografías del Museo Arqueológico de Valladolid. Valladolid.

NAH Noticiario Arqueológico Hispánico. Madrid.

OArqP O Arqueólogo Português. Lisboa.

PitTM Publicaciones de la Institución Tello Téllez de Meneses. Palencia.

QPAC Quadernos de Prehistoria i Arqueología Castellonenses. Castellón.

RA Revista de Arqueología. Madrid.

Rabm Revista de Archivos, Bibliotecas y Museos. Madrid.

RG Revista de Guimarães. Guimarães.

RHA Revisiones de Historia Antigua. VitoriaGasteiz.

RUC Revista de la Universidad Complutense. Madrid.

SA Studia Archaeologica. Valladolid.

SH Studia Historica. Salamanca.

TP Trabajos de Prehistoria. Madrid.

Abad CASAL, L., 1983: "Un conjunto de materiales de La Serreta de Alcoy”, Lucentum. 2, 173-197. Alicante.

Abásolo, J. A. y García, R., 1993: Excavaciones en Sasamón (Burgos), (EAE, 164). Madrid.

AbÁsolo, J. A. y RuIZ, I., 1976-77: "El yacimiento arqueológico de Castrojeriz. Avance al estudio de las cerámicas indígenas", Sautuola, II, 263-280. Santander.

AlarçAO, J., 1975: Cerâmica comum local e regional de Conimbriga, (Suplementos de Biblos, 8). Coímbra.

AlmeidA, C. A. F., 1974: "Cerâmica castreja", RG, 84 (14), 171-197. 
Álvarez Sanchís, J. R., 1999: Los vettones, (BAH, 1). Madrid.

APARICIO PÉREZ, J., 1976: "El culto en cuevas en la región valenciana", Homenaje a García Bellido, I (Revista de la Universidad Complutense, XXV, 101), 9-30. Madrid.

- 1997: "El culto en cuevas y la religiosidad protohistórica”, QPAC, 18, 345-358.

Arenas Esteban, J. A., 1987-88: "El poblado protohistórico de El Pinar (Chera, Guadalajara)", Kalathos, 7-8, 89-114. Teruel.

- 1999: La Edad del Hierro en el Sistema Ibérico Central, España, (BAR, Int. Ser., 780). Oxford.

Argente, J. L., Díaz, A. y Bescós, A., 2001: Tiermes V. Carratiermes necrópolis celtibérica. Campañas 1977 y 1986-1991, (Arqueología en Castilla y León, Memorias 9). Valladolid.

Arlegui Sánchez, M., 1992: "Las cerámicas de Numancia con letrero ibérico", en C. de la Casa (Dir.) $2^{\circ}$ Symposium de Arqueología Soriana. Actas, (Col. Temas Sorianos, 20), 473-494. Soria.

BALADO PACHÓN, A., 1999: "Intervención arqueológica en las murallas del Castro de Las Labradas en Arrabalde (Zamora)", AIEZFO, 17-42.

Barrientos, J., 1935-36: "Sobre la antigua Cauca", BSAA (Fascs. XI-XII), 141-142 y Láms. 27-31.

Barrio Martín, J., 1999: La Segunda Edad del Hierro en Segovia (España). Estudio arqueológico del territorio y la cultura material de los pueblos prerromanos. (BAR, Int. Ser., 790). Oxford.

- 2002: "El santuario de culto doméstico del poblado prerromano de Cuéllar (Segovia). Un análisis del contexto arqueológico y de los elementos rituales", $M M$, 43, 79-122.

Barrio Martín, J. y Alonso Mathias, F.,1999: "La datación del carbono 14 para el poblado prerromano de Cuéllar (Segovia, España)", en R. de Balbín y P. Bueno (Eds.) II Congreso de Arqueología Peninsular. T. III, Primer Milenio y Metodología, 289-302. Madrid.

Beirão, C. M. y Gomes, M. V., (1985) "Grafitos da Idade do Ferro do Centro e Sul de Portugal”, en J. de Hoz (Ed.) Actas del III Coloquio de Lenguas y Culturas Paleohispánicas (Acta Salmanticensia, 162), 465-499. Salamanca.

Beirão, C. M., Silva, C. T, Soares, J., Gomes, M. V. y Gomes, R. V., (1985) "Depósito votivo da II Idade do Ferro de Garvão. Noticia da primera campanha de excavações", OArqP, Sér. IV, 3, 45-136.

Beirão, C. M., Silva, C. T., Gomes, M. V. y Gomes, R. V., (1987) "Um depósito votivo da II Idade do Ferro de Garvão, no Sul de Portugal, e as suas relações com as culturas da Meseta", Actas del IV Coloquio de Lenguas y Culturas Paleohispánicas (Veleia 2-3), 207221. Vitoria.

BELtRÁn LlORIS, M., 1978: Cerámica romana: tipología y clasificación. Zaragoza.

- 1980: "Cerámica romana: Campaniense". APAA, I, 220223.

Berrocal-RAngel, L., 1989-90: "Cambio cultural y Romanización en el Suroeste Peninsular”, Anas, 2/3, 103-122. Sevilla.

- 1994: El altar prerromano de Capote. Ensayo etno-arqueológico de un ritual céltico en el Suroeste peninsular. Madrid.

1998: La Baeturia. Un territorio prerromano en la baja Extremadura, (Col. Arte-Arqueología, 20). Badajoz.

Blanco García, J. F., 1988: “Coca arqueológica”, $R A$, $81,46-55$.

- 1991: Los hornos de cerámica vaccea de Coca (Segovia). Memoria inédita de la excavación depositada en el Servicio Territorial de Cultura de la Junta de Castilla y León en Segovia.

1992a: "El complejo alfarero vacceo de Coca (Segovia)", RA, 130, 34-41.

- 1993a: "Excavación en la Avda. de la Constitución. Coca (Segovia)", Numantia. Arqueología en Castilla y León 1989/1990, 4, 159-173. Valladolid.

1993b: "La cerámica celtibérica gris estampillada en el centro de la Cuenca del Duero. Las producciones de Coca (Segovia)", BSAA, LIX, 113-139.

- 1994: "El castro protohistórico de La Cuesta del Mercado (Coca, Segovia)", CuPAUAM, 21, 35-80.

1995: "Representaciones figurativas en la cerámica celtibérica pintada de Cauca y el castro de la Cuesta del Mercado", en V. Oliveira Jorge (Coord.) $1{ }^{\circ}$ Congresso de Arqueología Peninsular, Actas V, 213-232. Porto.

1997: "Zoomorfos celtibéricos en perspectiva cenital. A propósito de los hallazgos de Cauca y el castro 'Cuesta del Mercado' (Coca, Segovia)", Complutum, 8, 183-203. Madrid.

1998a: "Las producciones cerámicas del alfar vacceo de Cauca (Coca, Segovia)", MM, 39, 121-141.

1998b: "La Edad del Hierro en Sepúlveda (Segovia)", Zephyrus, LI, 137-174. Salamanca.

- 2002: "Vasos de imitación metálica en el Valle del Duero", Guión del Curso de la Fundación Universidad de Verano de Castilla y León Los Vacceos: Arqueología y Fuentes, dir. por C. Sanz Mínguez y F. Romero Carnicero. Abadía de Retuerta-Peñafiel, 8-11 de julio de 2002. Valladolid. 
- 2003 Cerámica histórica en la provincia de Segovia. I, Del Neolítico a época visigoda. (V Milenio - 711 d.c.). Segovia.

Blasco, M ${ }^{\text {a }}$ C. y Alonso, Ma A., 1985: Cerro Redondo. Fuente el Saz del Jarama, Madrid. (EAE, 143). Madrid.

BlASCO , M ${ }^{\text {a }}$ C. y BARRIO, J., 1991: "Las necrópolis de Carpetania”, en J. Blánquez y V. Antona (Coords.) Congreso de Arqueología Ibérica. Las Necrópolis, (U.A.M., Varia I), 279-312. Madrid.

BLASCO, Mª C. y LUCAS, M ${ }^{a}$ R., 1999: "El sustrato de La Carpetania y su relación con los orígenes del mundo celtibérico", en J. A. Arenas y $\mathrm{M}^{\mathrm{a}} \mathrm{V}$. Palacios (Coords.) El Origen del Mundo Celtibérico. Actas de los Encuentros sobre el Origen del Mundo Celtibérico, 239-252. Guadalajara.

BlázQuez Martínez, J. M., 1983: Primitivas religiones ibéricas. T. II, Religiones prerromanas. Madrid.

Bonet Rosado, H., 1995: El Tossal de Sant Miquel de Llíria. La antigua Edeta y su territorio. Valencia.

Bonet Rosado, H. e IzQuierdo Peraille, I., 2001: "Vajilla ibérica y vasos singulares del área valenciana entre los siglos III y I a. C.”, APL, XXIV, 273-313.

Broncano Rodríguez, S. (1989) El depósito votivo ibérico de El Amarejo. Bonete (Albacete). (EAE, 156). Madrid.

Burillo Mozota, F., 1997: "Textos, cerámicas y ritual celtibérico", Kalathos, 16, 223-242. Teruel.

Cabré Aguiló, J., 1930: Excavaciones de Las Cogotas, Cardeñosa (Ávila). I, El Castro, (MemJSEA, 110). Madrid.

- 1932: Excavaciones de Las Cogotas, Cardeñosa (Ávila). II, La Necrópolis, (MemJSEA, 120). Madrid.

Cabré, J., Cabré, Ma E. y Molinero, A., 1950: El Castro y la Necrópolis del Hierro Céltico de Chamartín de la Sierra (Ávila), (AAH, V). Madrid.

Carretero Vaquero, S., 2000: El campamento romano del Ala II Flavia en Rosinos de Vidriales (Zamora): la Cerámica. Zamora.

CASTiella, A., 1977: La Edad de Hierro en Navarra y Rioja. Pamplona.

Castro García, L. y Blanco Ordás, R., 1975: "El Castro de Tariego de Cerrato (Palencia)", PITTM, $35,55-138$.

Cela Espín, X., 1994: "La cerámica ibérica a torno en El Penedès”, Pyrenae, 25, 151-180. Barcelona.

Celis SÁNChEZ, J., 1990: "Apuntes para el estudio de la secuencia ocupacional de La Dehesa de Morales, Fuentes de Ropel, Zamora", Primer Congreso de Historia de Zamora. T. II, Prehistoria e Historia Antigua, 467-495. Zamora.
- 1996: "Origen, desarrollo y cambio en la Edad del Hierro de las tierras leonesas", en L. A. Grau (Coord.) ArqueoLeón, 41-67. León.

Cuadrado, E. y Quesada, F., 1989: "La cerámica ibérica fina de 'El Cigarralejo' (Murcia). Estudio de cronología”, Verdolay, 1, 49-115. Murcia.

Delibes, G. y EsparZA, A., 1989: "Los tesoros prerromanos de la Meseta Norte y la orfebrería celtibérica", en J. A. García Castro (Dir.) El Oro en la España Prerromana (RA, Extra 4), 108-129. Madrid.

Delibes , G., Esparza, A. y Martín Valls, R., 1997: "Los tesoros prerromanos de Arrabalde (Zamora)", en J. Arce, S. Ensoli y E. La Rosa (Eds.) Hispania Romana. Desde Tierra de Conquista a Provincia del Imperio, 60-65. Madrid.

Delibes , G. y Martín Valls, R., 1982: El tesoro de Arrabalde y su entorno histórico. (Guía de la Exposición). Zamora.

Delibes , G., Romero, F., SAnZ, C., Escudero, Z. y SAN Miguel, L. C., 1995: "Panorama arqueológico de la Edad del Hierro en el Duero medio", en G. Delibes, F. Romero y A. Morales (Eds.) Arqueología y Medio Ambiente. El Primer Milenio a. C. en el Duero Medio, 47146. Valladolid.

DíAz DíAz, A., 1976: "La cerámica de la necrópolis celtibérica de Luzaga (Guadalajara) conservada en el Museo Arqueológico Nacional”, RABM, LXXIX (1), 397-489.

Esparza Arroyo, A., 1986: Los castros de la Edad del Hierro en el Noroeste de Zamora. Zamora.

FERNÁNDEZ GÓMEz, F., 1986: Excavaciones arqueológicas en El Raso de Candeleda, 2 vols. Ávila.

Fernández Gómez, F. y López Fernández, M. T.,1990: "Secuencia cultural de El Raso de Candeleda (Ávila)", Numantia. Arqueología en Castilla y León, III, 95-124. Valladolid.

García Bellido, M. P., 1999: "Sistemas metrológicos, monedas y desarrollo económico", en F. Burillo (Coord.) IV Simposio sobre Celtíberos. Economía, 351385. Zaragoza.

García Heras, M., 1998: Caracterización arqueométrica de la producción cerámica numantina, (BAR, Int. Ser., 692). Oxford.

García Huerta, M ${ }^{\mathrm{a}}$ R., 1989: La Edad del Hierro en la Meseta Oriental: el Alto Jalón y el Alto Tajo, (Col. Tesis Doctorales de la U.C.M.). Madrid.

García Huerta, Ma R. y Antona del Val, V., 1992: La necrópolis celtibérica de La Yunta (Guadalajara). Campañas 1984-1987. Guadalajara.

Gil-MASCARELL, M., 1975: "Sobre las cuevas ibéricas del 
País Valenciano. Materiales y problemas”, PLAV, II, 281-232. Valencia.

- 1977: "Excavaciones en la cueva-ritual ibérica de Villagordo del Cabriel (Valencia)", XIV CNA, 705712.

Gómez Pérez, A. y Sanz Mínguez, C., 1993: "El poblado vacceo de Las Quintanas, Padilla de Duero (Valladolid): Aproximación a su secuencia estratigráfica”, en F. Romero, C. Sanz y Z. Escudero (Eds.) Arqueología Vaccea. Estudios sobre el Mundo Prerromano en la Cuenca Media del Duero, 335-370. Valladolid.

Gozalo Viejo, F., 1980: El yacimiento del Cerro Tormejón. Armuña, Segovia. Memoria de Licenciatura leída en la U.A.M. Madrid. (Inédita)

Heredero García, R., 1993: "Casas circulares y rectangulares de época vaccea en el yacimiento del Cerro del Castillo (Montealegre)", en F. Romero, C. Sanz y Z. Escudero (Eds.) Arqueología Vaccea. Estudios sobre el Mundo Prerromano en la Cuenca Media del Duero, 279-302. Valladolid.

Jaeggi, O., 1999: Der Hellenismus auf der Iberischen Halbinsel. Studien zur Iberischen Kunst und Kultur: das Beispiel einer Rezeptionsvorgangs, (Iberia Archaeologica, 1). Mainz am Rhein.

Jimeno Martínez, A., 2000: "El origen del urbanismo en el Alto Duero" Soria Arqueológica, 2, 239-262. Soria.

Juan Tovar, L. C. y Blanco García, J. F., 1997: "Cerámica común romana, imitación de sigillata, en la provincia de Segovia. Aproximación al estudio de las producciones cerámicas del siglo $\mathrm{V}$ en la Meseta Norte y su transición al mundo hispano-visigodo", AEspA, 70, 171-219.

Labeaga Mendiola, J. C., 1985: "Copas de pie alto en La Custodia, Viana (Navarra)”, XVII CNA, 573-584.

- 1999-2000: La Custodia, Viana, Vareia de los Berones, (TAN, 14). Pamplona.

LORRIO, A. J., 1988-89: “Cerámica gris orientalizante de la necrópolis de Medellín (Badajoz)”, Zephyrus, XLIXLII, 283-314. Salamanca.

- 1989: "Las cerámicas 'celtibéricas' de Segobriga”, M. Almagro y A. Lorrio, Segobriga III. La Muralla Norte y la Puerta principal. Campañas 1986-1987, 249-298. Cuenca.

LUCAS, Mª R. y ViñAS, V., 1971: "Nuevos mosaicos romanos y otros hallazgos arqueológicos en la provincia de Segovia”, ES, XXIII, 71-104.

Marco Simón, F., 1983-84: "Consideraciones sobre la religiosidad celtibérica en el ámbito turolense", Kalathos, 3-4, 71-93. Teruel.
Martí Bonafé, Ma A., 1990: "Las Cuevas del Puntal del Horno Ciego. Villagordo del Cabriel. Valencia", Saguntum, 23, 141-182. Valencia.

Martín VAlls, R., 1971: "El castro de Picón de la Mora (Salamanca)", BSAA, XXXVII, 125-144.

- 1986-87: "La Segunda Edad del Hierro: consideraciones sobre su periodización”, Zephyrus XXXIX-XL, 5986. Salamanca.

- 1990: “Los 'simpula' celtibéricos”, BSAA, LVI, 144-169.

Martín Valls, R. y Esparza Arroyo, A., 1992: "Génesis y evolución de la Cultura Celtibérica", en M. Almagro Gorbea y G. Ruiz Zapatero (Eds.) Paleoetnología de la Península Ibérica, (Complutum 23), 259-279. Madrid.

Martínez Perona, J. V., 1992: "El santuario ibérico de la Cueva Merinel (Bugarra). En torno a la función del vaso caliciforme", Estudios de Arqueología Ibérica y Romana. Homenaje a Enrique Pla Ballester (Serie de Trabajos Varios del S.I.P., 89), 261-281. Valencia.

Mata Parreño, C. y Bonet Rosado, H., 1992: "La cerámica ibérica: ensayo de tipología”, Estudios de Arqueología Ibérica y Romana. Homenaje a Enrique Pla Ballester (Serie de Trabajos Varios del S.I.P., 89), 117173. Valencia.

Molinero, A., 1971: Aportaciones de las excavaciones y hallazgos casuales (1941-1959) al Museo Arqueológico de Segovia. (EAE, 72). Madrid.

Morales Hernández, F., 1995: Carta Arqueológica. Soria. La Altiplanicie Soriana. Soria.

Morel, J. P., 1981: Ceramique Campanienne: les formes. París.

Palol, P. de y Wattenberg, F., 1974: Carta arqueológica de España. Valladolid.

Perales García, M ${ }^{\mathrm{a}}$ P., 1989: Introducción al poblamiento ibérico en Mora de Rubielos (Teruel), (Monografías Arqueológicas del S.A.E.T., 2). Teruel.

Pereira Sieso, J., 1987: "Imitaciones ibéricas de cráteras áticas procedentes de Gor (Granada)", XVIII CNA, 701-711.

- 1988: "La cerámica ibérica de la cuenca del Guadalquivir. I. Propuesta de clasificación”, TP, 45, 143-173.

Pérez González, C. y Blanco García, J. F., 2000: "Nuevas investigaciones arqueológicas en Cauca", $R A, 228,38-47$.

PIÑEL, C., 1976: "Materiales del poblado de Las Paredejas en el Cerro del Berrueco. Una nueva arracada", Zephyrus, XXVI-XXVII, 351-368. Salamanca. 
Pla Ballester, 1980: "Los Iberos", Nuestra Historia. T. I, Valencia, 197-272. Valencia.

Posac Mon, C. F., 1952: "Solosancho (Ávila)", NAH, 13, 63-74.

PrinciPal-Ponce, J., 1998: Las importaciones de vajilla fina de barniz negro en la Cataluña sur y occidental durante el siglo III a. C. Comercio y dinámica de adquisición en las sociedades indígenas. (BAR, Int. Ser., 729). Oxford.

Py, M., 1993: "Campaniense A", Lattara, 6, 146-150. Lattes.

RADDATZ, K., 1969: Die Schatzfunde der Iberischen Halbinsel vom Ende des drittenbis zur Mitte des ersten Jahrhunderts vor Christi Geburt. Untersuchungen zur Hispanischen Toreutik. (MF, 5). Berlín.

Risch, R., Carbonell, J., Soldevilla, J. A. y Hernando, P., 1986: "La innovación tecnológica como aportación al análisis de complejos socio-culturales", Arqueología Espacial, 9. Coloquio sobre el Microespacio - 3. Del Bronce Final a Época Ibérica, 285301. Teruel.

Romero Carnicero, M. V., Romero Carnicero, F. y Marcos Contreras, G. J. 1993: “Cauca en la Edad del Hierro. Consideraciones sobre la secuencia estratigráfica”, en F. Romero, C. Sanz y Z. Escudero (Eds.) Arqueología Vaccea. Estudios sobre el Mundo Prerromano en la Cuenca Media del Duero, 223-261. Valladolid.

Ruiz, L., 1991-92: "La cueva santuario ibérica del Cerro del Castillo", APA, 7-8, 83-86.

SACRISTÁn, J. D., 1986: La Edad del Hierro en el Valle Medio del Duero. Rauda (Roa, Burgos). Valladolid.

SAnMartí Greco, E., 1992: "Nouvelles données sur la chronologie du camp de Renieblas à Numance (Soria, Castilla-León, Espagne)", DocAMèrid, 15, 417430.

Santos Yanguas, N., 1979: "El tesoro prerromano de Arrabalde (norte de Zamora)”, MHA, III, 273-276.

SANZ GAMO, R., 1997: Cultura ibérica y romanización en tierras de Albacete: los siglos de transición. Albacete.

Sanz Mínguez, C., 1993: "Uso del espacio en la necrópolis celtibérica de Las Ruedas, Padilla de Duero (Valladolid): cuatro tumbas para la definición de una estratigrafía horizontal", en F. Romero, C. Sanz y Z. Escudero (Eds.) Arqueología Vaccea. Estudios sobre el Mundo Prerromano en la Cuenca Media del Duero, 371-396. Valladolid.

- 1997: Los Vacceos: cultura y ritos funerarios de un pueblo prerromano del valle medio del Duero. La necrópolis de Las Ruedas, Padilla de Duero (Valladolid). (Arqueología en Castilla y León, Memorias 6). Salamanca.
- 1999: "La cerámica a peine, nuevos datos para la definición de un estilo impreso en el Grupo Vacceo", en R. de Balbín y P. Bueno (Eds.) II Congreso de Arqueología Peninsular. T. III, Primer Milenio y Metodología, 249-273. Madrid.

Sanz Mínguez, C. y Escudero Navarro, Z., 1994: "Nuevos datos sobre las fíbulas de'longo travessão sem espira'. La aportación de la Submeseta Norte peninsular", BSAA, LX, 154-170.

Sanz Mínguez, C., Gómez Pérez, A. y Arranz Mínguez, J. A., 1993: "La necrópolis vaccea de Carralaceña, un nuevo conjunto funerario del complejo arqueológico Padilla-Pesquera de Duero (Valladolid)", Numantia. Arqueología en Castilla y León 1989/1990, 4, 129-147. Valladolid.

Schulten, A., 1928: Cauca (Coca) una ciudad de los celtíberos. Segovia.

Sievers, V. S., Gebhard, R., Leicht, M., Schwab, R., Völkel, J., Weber, B. y Ziegaus, B., 2000: "Vorbericht über die Ausgrabungen 1998-1999 im Oppidum von Manching”, Germania, 78, 355-394. Mainz am Rhein.

Silva, A. C. F., 1986: A Cultura Castreja no Noroeste de Portugal. Paços de Ferreira.

TARACEnA, B., 1929: Excavaciones en las provincias de Soria y Logroño, (MemJSEA, 103). Madrid.

- 1941: Carta Arqueológica de España. Soria. Madrid.

Urbina Martínez, D., 2000: La Segunda Edad del Hierro en el Centro de la Península Ibérica, (BAR, Int. Ser., 855). Oxford.

WATtenberg García, E., 1978: Tipología de cerámica celtibérica en el valle inferior del Pisuerga (yacimientos de Tariego, Soto de Medinilla y Simancas), (MMAV, 3). Valladolid.

Wattenberg Sanpere, F., 1959: La Región Vaccea. Celtiberismo y romanización en la Cuenca Media del Duero, (BPH, II). Madrid.

- 1963: Las cerámicas indígenas de Numancia, (BPH, IV). Madrid.

- 1978: Estratigrafía de los cenizales de Simancas (Valladolid), (MMAV, 2). Valladolid.

Zamora Canellada, A., 1975: "Cerámica celtibérica en la capital segoviana”, ES, XXVII (n. 79), 33-41.

- 1987: "Segovia en la Antigüedad”, en J. T. Arribas (Coord.) Historia de Segovia, 20-55. Segovia. 